\title{
The Quest for Liberation-in-Life
}

\section{A Survey of Early Works on Haṭa- and Rājayoga}

\author{
Jason Birch
}

The Hatha- and Rājayoga texts which were composed before the Hathapradīpikā (mid-fifteenth century CE) provide a window onto what might be considered the formative phase of these types of yoga. Liberation (mokșa, mukti, etc.) is mentioned frequently throughout this literature. Although the practice of Hatha- and Rājayoga is said to bestow supernatural powers (siddhi) and mundane benefits, such as healing diseases, both yogas are undoubtedly soteriological because their main aim is to bring about liberation from transmigration (saṃsāra).

The survey of the early Hatha- and Rajjayoga corpus in this chapter reveals that a fundamental premise for the attainment of liberation is the successful practice of yoga. The culmination of the practice is a profound state of meditation, in which the yogin does not breathe, think, or move. This meditative state is called various names, such as rājayoga, amanaska, unmanì, laya, samādhi, nirālamba, and sahaja, which tend to be used interchangeably in these works. ${ }^{1}$ In this chapter, I shall refer to it by the generic term samādhi. On the whole, samādhi is the necessary and sufficient cause for liberation in Hatha- and Rājayoga texts. Even though gnosis (jñ̄ana) and ritual (kriȳa) may be mentioned in these works, both are unimportant for the attainment of samädhi, if not altogether superfluous. Although in some cases gnosis may characterize the liberated state, the study of scripture or the contemplation of doctrinal truths is not presented as a principal means to liberation.

The survey of this corpus further reveals that the ultimate goal of the prescribed yogas is the attainment of liberation-in-life (jivanmukti). That is to say, the yogin remains alive after liberation, as opposed to being liberated at death, which was the default position, as it were, of Vedic Brahmanical religions. Seeing that these works tend to expound on practical matters and avoid, perhaps deliberately, philosophical or theoretical concerns, statements about the nature of liberation are in many cases piecemeal and not entirely consistent. Nonetheless, it is clear

${ }^{1}$ For a longer list of these terms, see Hathapradīpikā 4.2-4.4. The earliest works to use these terms as though they were synonyms include the Amanaska, the Candrāvalokana, and the Yogatārāvalī. These terms refer to the same state of samädhi because, unlike the Pätañjalayogaśästra, Hațha- and Rājayoga texts do not teach stages of samādhi that would suggest differences in their meaning. 
that at least two different conceptions of the liberated yogin are presented. Some texts emphasize the liberated yogin's complete transcendence of the world, which is implied by his blissful state of minimal physical and mental activity, whereas other texts state explicitly the yogin's power to act in the world at will. I have attempted to understand these differences within the framework of 'freedom from' (moksa) and 'freedom to' (siddhi), bearing in mind, as Watson, Goodall, and Sarma (2013: 19) have noted, that this dichotomy is 'useful not because we can equate one kind with liberation, but because we see how the two kinds are differentially present within the various liberation doctrines'

Most of the early works on Hatha- and Rājayoga have not been critically edited or translated into English. Section 1 of this chapter ('Corpus of Early Hatha- and Rājayoga') will provide the first survey of teachings on samädhi and liberation in these works. Section 2 addresses the meaning of the term räjayoga and section 3 discusses the relationship between Rājayoga and liberation-in-life, an essential conception of which can be traced back to earlier Kaula traditions. Section 4 of the chapter will examine how Rājayoga and liberation were understood in the Hathapradipika, which is largely an anthology of the teachings of the early Hathaand Rājayoga texts (Bouy 1994: 40). I attempt to answer the more specific question of how its author Svātmārāma resolved the tension between transcendence and power, which is apparent in many of the works he used for the Hathapradipikā. My research concludes that Svātmārāma favoured 'freedom from' by regarding the attainment of samädhi as identical with liberation and, in so doing, tends to understate the siddhi-orientated liberation.

\section{Corpus of Early Hațha- and Rājayoga}

The early works of Hatha- and Rājayoga have been identified by the verses which Svātmārāma borrowed for his Hațapradīpikā. ${ }^{2}$ The estimates for their date of composition are based on the textual borrowings between them and other Sanskrit works. ${ }^{3}$ It should be noted that not all of the yoga texts in this corpus name their systems of yoga as Hatha- or Rājayoga. Nonetheless, so much of their theory and practice is similar or, at least, relevant to one another that all of them should be considered important for understanding the early formative phase of these types of yoga. I have ordered the texts according to the theme of

\footnotetext{
${ }^{2}$ Since one of the main concerns of this chapter is to assess how Svātmārāma synthesized earlier conceptions of Rājayoga and liberation in his Hathapradīpikā, I have excluded some works that teach techniques of Hathayoga before the fifteenth century, which were not a source for the Hathapradipikā. Examples include the Amaraughaśāsana and the yoga sections of the Särngadharapaddhati. For the same reason, I have not included a few works of this period in other languages, which incorporate either techniques or systems of Haṭha- or Rājayoga, such as the Jñanneśvarī, Vivekadarpaṇa, Tattvasāra, and Vivekasindhu.

${ }^{3}$ For information on the dates of these works, see Birch 2011: 528 and Birch 2018a: 5-8.
} 
transcendence (i.e. 'freedom from') and power (i.e. 'freedom to'). Those at the beginning more closely equate liberation with the transcendent state of samādhi, whereas those towards the end describe more explicitly the liberated yogin's power to act in the world. Those in the centre do not clearly emphasize one or the other.

Vivekamärtanda (twelfth to thirteenth century)

Candrāvalokana (fourteenth century)

Yogatārāvalì (fourteenth century)

Amanaska, chapter two (eleventh to early twelfth century)

Gorakșaśataka (early fourteenth century)

Vasisthasamithitā (twelfth century) and the Yogayajjñavalkya (thirteenth to fourteenth century)

Amrtasiddhi (eleventh century)

Amaraughaprabodha, short redaction (twelfth century)

Dattātreyayogaśāstra (thirteenth century)

Yogabija (thirteenth to fourteenth century)

Khecarividya (thirteenth to fourteenth century)

Sivasamhitā (fifteenth century)

\subsection{The Vivekamārtanda}

The Vivekamārtanda teaches a yoga with six auxiliaries (sadanga), which it does not identify as either Hatha- or Rājayoga. However, this Saiva text contains one of the earliest accounts of Hathayogic mudrās, including the three bandhas, namely, mūlabandha, uddìn̄nabandha, jālandharabandha, mahāmudrā khecarī, and viparitakarana. The aim of its yoga is liberation. In fact, the Vivekamārtanda twice refers to itself as a 'ladder to liberation' $(1,198)$. The role of its auxiliaries in the attainment of liberation is stated as follows:

Diseases are cured by yogic posture (āsana), sin is [destroyed] by holding the breath (prānāyāma) and the best of yogins cures his mental disturbances by withdrawing [his mind from sense objects] (pratyāhāra). Stability of the mind is produced by concentration (dhāraṇā), wondrous power by meditation (dhyāna) and [the yogin] obtains liberation by samādhi, after having abandoned [all] action, good and bad. ${ }^{4}$

4 Vivekamārtanḍa 92-3 (āsanena rujo hanti prānāyāmena pātakam | pratyāhāreṇa yogīndro vikārạ̣ hanti mānasam ||92|| dhāranayā manodhairyạ̣ dhyānād aiśvaryam adbhutam | samādher mokṣam āpnoti tyaktvā karma śubhäśubham ||93|| 93a dhāranayā mano- ] Nowotny Ed.: dhāraṇā manaso Codex). 
The verses following the above passage indicate how the yogin progresses through the auxiliaries:

By [practising] breath retentions twelve times, withdrawal from sense objects is said [to occur]. By practising this withdrawal twelve times, good concentration arises. The practice of concentration twelve times is said to be meditation by those skilled in meditation. By practising meditation twelve times, it is called samādhi. The fruit of samādhi is the [appearance of] a light, unbounded on all sides. When it is seen, rites, action and [whatever] comes and goes cease. ${ }^{5}$

The definition of samädhi refers to the time spent in meditation. A subsequent verse elaborates on this by saying that concentration arises after two hours, meditation after a day, and samādhi after twelve days. ${ }^{6}$ The Vivekamārtanda finishes with a lengthy description of samädhi, which is consistent with that of other texts in this corpus. The Vivekamārtanda does not mention liberation-in-life nor does it discuss liberation generally. The fact that the text ends with the following passage on samädhi suggests that its teachings aimed at complete transcendence of the world:

When the self and mind unite because of yoga, just as the fusion of salt and water by being mixed, it is called samädhi. When the breath perishes and the mind dissolves, and then the state of coalescence arises, it is called samädhi. In this system, the state of oneness of the individual self with the supreme self, in which all intentional thinking has disappeared, is called samādhi. [...] The yogin immersed in samādhi does not cognise smell, taste, form, touch, sound, himself nor another. The yogin immersed in samādhi is not aware of hot and cold, suffering and happiness nor pride and disgrace. The yogin immersed in samädhi is not consumed by time, troubled by [the fruits of] action nor afflicted by disease. The yogin immersed in samādhi is not pierced by any weapon, cannot be killed by anyone nor controlled by mantras and magical devices. The knowers of the reality [revealed by samädhi] know it to be without beginning or end and devoid of support, multiplicity, foundation, illness and form. The knowers of Brahman know it to be unmoving, untainted, eternal, without action and free of qualities. It is the great void, consciousness and bliss. Like milk poured into milk, ghee in ghee and fire in fire, the yogin immersed in samādhi becomes absorbed in that. ${ }^{7}$

${ }^{5}$ Vivekamārtanḍa 94-6 (prānāyāmadvișațkena pratyāhārah prakīrtitah | pratyāhāradvișațena jāyate dhārañā śubhā ||94|| dhāranādvādaśa proktam dhyānam dhyānaviśāradaih | dhyānadvādaśakenaiva samādhir abhidhīyate ||95|| yat samādhiphalam jyotir anantạ̣ viśvatomukham | tasmin drsțe kriyā karma yātāyātam nivartate ||96|| 95b -viśāradaih ] Nowotny Ed.: -viśārādeh Codex. 95c -daśakenaiva ] emend.: -daśakoneva Codex).

6 Vivekamārtanda 161 (dhāraṇā pañcanādì syād dhyānam vai șaștinādikam|dinadvādaśakena syāt samādhih prānasamyamāt ||).

7 Vivekamārtanḍ 162-64, 166-72 (ambusaindhavayoh sāmyam yathā bhavati yogatah | tathātmamanasor aikyam samādhih so 'bhidhīyate ||162|| yad̄̇ saṃkṣìyate prāno mānasam ca vilìyate | 


\subsection{The Candrāvalokana}

The Candrāvalokana, which probably dates to the fourteenth century, ${ }^{8}$ is a short dialogue between Śiva and Matsyendranātha. The name of the text, which literally means 'looking at the moon', may be connected to esoteric explanations of the days of the new moon (amāvāsyā), lunar fortnight (pratipat), and full moon (paurnamāsi $)$, as well as the practice of impeding the downward flow of nectar from the moon in the head. The Candrāvalokana does not refer to its yoga by the name Hațha- or Rājayoga. However, it teaches techniques, such as śämbhavì $m u d r \bar{a}$, with terminology and concepts that are characteristic of these yogas. The overall aim of the text is gnosis of Brahman, which is achieved by dissolving mind and breath and stopping the outward flow of nectar from the moon.

The first half of the Candrāvalokana focuses on achieving dissolution (laya) of the mind and breath by fixing the gaze (drst $t i)$. The importance of dissolution for attaining gnosis and liberation is stated as follows:

How can gnosis exist in the mind when the mind does not die because the breath is alive? [When his] mind and breath dissolve, that man becomes liberated. There is no other way whatsoever. ${ }^{9}$

The second half of the work, which was redacted as part of the Yogakundalyupanișat (Bouy 1994: 41, 101), aims at stopping the flow of nectar from the moon by

tadā samarasatvam ca samādhih so 'bhidhīyate ||163|| yat samatvaṃ dvayor atra jīvātmaparamātmanoh | samastanaștasan்kalpam samādhih so 'bhidhīyate ||164|| na gandham na rasam rūpam na ca sparśạ̣ na nisvanam | nātmānam na param vetti yogī yuktah samādhinā ||166|| näbhijānäti śîtoșnam na duhkham na sukham tathā | na mānam nāpamānam ca yoḡ yuktah samādhinā ||167|| khādyate na ca kālena bādhyate na ca karmañā | pìdyate na ca rogena yogī yuktah samādhinā ||168|| abhedyah sarvaśastrānām avadhyah sarvadehinām | agrāhyo mantrayantrānām yoḡi yuktah samādhinā ||169|| nirādyantam nirālambaṃ niṣprapañcam nirāśrayam | nirāmayam nirākāram tattvam tattvavido viduh ||170|| niścalam nirmalạ̣ nityam niḥkriyam nirguṇam mahat | vyoma vijñānam ānandam brahma brahmavido viduh||171|| dugdhe kșīram ghṛte sarpir agnau vahnir ivārpitah | tanmayatvam vrajaty eva yogī yuktah samādhinā ||172|| 162a ambusaindhavayoh ] emend.: am+saidhavayoh Codex. 164c. -sańkalpaṃ] emend.: -sankkalpah Codex. 166c nisvanam ] emend.: nisvaram Codex.168a khādyate ] Nowotny Ed.: pīdyate Codex. 169a śastrānāạn ] corr.: śāstrānām Codex. 169c mantrayantrānāạm ] Nowotny Ed.: mantratantrānām Codex).

8 The Candrāvalokana's terminus ad quem is the Hathapradīpikā (Bouy 1994: 14; Mallinson 2014: 244-5) and its terminus ad quo is probably the Amanaska (2.10=Candrävalokana 1$)$ or the Anubhavanivedanastotra (1-2 = Candrāvalokana 2-3). The latter is attributed to Abhinavagupta by tradition. If the author of the Anubhavanivedanastotra were Abhinavagupta, then the Candrāvalokana would have been written after the tenth century. However, the Anubhavanivedanastotra may be more recent. Its attribution to Abhinavagupta is doubtful because it contains terminology not found in Abhinavagupta's other works, such as śämbhavī mudrā, which is called parabhairavamudrā in his Māliniślokavārttika and bhairavamudrā by his student Kșemarāja (Birch 2014: 408, 425).

${ }_{9}$ Candrāvalokana 7 (jūānam kuto manasi jīvati $\dagger$ devi $\dagger$ tāvat prāne 'pi jīvati mano mriyate na yāvat | prāno mano dvayam idam vilayam prayāti mokșam sa gacchati naro na katham cid anyah ||7|| 7a

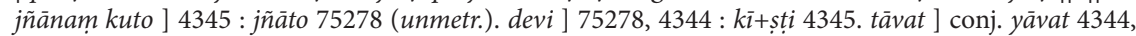
4354, 75278. prāne 'pi ] 75,278, 4344 : prāno 'pi 4345). Regarding the crux devi/kì+știi, the reading of devi is not possible because the Candrāvalokana is a dialogue between two males (i.e. Matsyendranātha and Śiva). 
moving the breath and śakti into the central channel and raising both upwards. Also, this involves a process of moving the breath into the six cakras and fixing it in the uppermost one (i.e. $\bar{a} j \tilde{n} \bar{a}$ ).

The Candrāvalokana seems to be entirely centred on liberation and does not mention a single siddhi. Although the teachings aim at transcending mind and death, ${ }^{10}$ the final words of Śiva suggest that Matsyendra, who is liberated by Śiva's favour after having heard the teachings, must return to the world:

[Śiva says,] 'son, go to the earth. You will save the three worlds.'

\subsection{The Yogatārāvali}

The Yogatārāvalì ('a string of stars on yoga') is the shortest known Sanskrit text on Hatha- and Rājayoga at only twenty-nine verses. Although nearly all the printed editions attribute this work to Sankarācārya, most of the manuscript colophons consulted for this study do not support this. ${ }^{12}$ The pattern of second-syllable rhyming and alliteration of the first syllable of a verse's quadrant ( $p \bar{a} d a)$ within that quadrant, which is unusual in Sanskrit works but more common in the poetry of South Indian vernacular languages, such as Tamil, strongly suggests this work was composed in South India. ${ }^{13}$ In the version of the text in printed editions, there are a few passing references to Vedāntic concepts, such as the four states of the Self referred to in Gaudapāda’s Māndūukyopaniṣatkārikā. However a few manuscripts, which may preserve a shorter, and perhaps older, version of the

${ }^{10}$ Candrāvalokana 38cd: 'Yogins go to immortality, which is the same as the oneness [achieved] through samādhi' (samādhinaikena samam amṛtam yānti yoginah).

11 Candrāvalokana 45cd (gaccha putra prthivyām tvam trailokyam coddharisyasi).

12 A descriptive catalogue of yoga manuscripts (Kaivalyadhama 2005: 232-9) reports seven manuscripts which attribute authorship to Govindabhagavatpūjyapāda, two to Nandiśvara, fourteen to Śankarācārya, and one to Sadāśiva. I have consulted most of these manuscripts and this catalogue is unreliable in regard to reporting authorship. For example, Ms No. 240-3748 Ānandāśramasamsthā; Ms No. 75278 Adyar Research Library; Ms No. 6722 Sarasvatī Mahal Library Thanjavur; Ms No. 7970 Oriental Institute, MSU Baroda; Ms No. P5682/3 Mysore Oriental Research Institute; Ms No. 18/2 Sringeri Sharada Peetham; and Ms No. SD5051, D4357-9 GOML do not attribute the authorship to anyone. I have not consulted all the manuscripts in the above catalogue but I can confirm that Ms No. D4357 GOML and SR1873 GOML attributes authorship to Govindabhagavatpūjyapāda; Ms No. SR2126 GOML to Nandīśvara; and Ms No. 6-4-399 Prajñāpāṭhaśālā, Wai and Ms No. SR7043 GOML to Śankarācārya. Ms No. SR6529 GOML has the title Yogatārāvalīstotra, which is attributed to Śankarācārya, but this text is a different redaction of the Yogatārāvalī. Also, Ms No. 72330 of the Adyar Research Library is a commentary on the Yogatārāvali by the name of the Rãjatarala, which was not composed by Śankarācārya. This work was composed (sometime after the eighteenth-century Maṇdalabrāhmaṇopanișat) by Rāmasvāmipaṇ̣ita, who is described as a worshipper of Śankarācārya’s feet (śrísaṃkarācāryapādakiṃkara). In my view, the text was probably attributed to Śankarācārya sometime after it was composed because three old palm-leaf manuscripts, which have been among the most valuable witnesses for reconstructing the text and one of which is held at the Sringeri Sharada Peetham, do not mention Śankarācārya. In fact, one of these (PUL, Ms. No. 412) attributes the work to Gorakșanātha.

${ }^{13}$ I would like to thank Dominic Goodall for pointing this out at a reading workshop, organized by the Hațha Yoga Project and the Ecole française d'Extrême-Orient, January 2018. 
text, do not have the verses with vedāntic concepts, suggesting that some material, including the last verse translated below, was added at a later time. ${ }^{14}$ Nonetheless, the text is largely free from doctrine and sectarian markers that might identify it with a particular religion or place. The date of composition was sometime after the Amanaska and before the Hathapradipikā (Birch 2015: 5-8).

The Yogatārāvali teaches a system of yoga in which Hathayoga is the chief means to Rājayoga. ${ }^{15}$ The physical practice of Hathayoga is the application of the three locks (bandha) during deliberate breath retentions. This induces a spontaneous breath retention called kevalakumbhaka, which in turn produces Rājayoga. The Yogatārāvalīs author made use of a similar array of synonyms for Rājayoga, such as amanaska, manonmanī, and yoganidrā, as is found in both the Amanaska's second chapter and the Hathapradipikā. A nod to the former is suggested by the use of amanaskamudrā in referring to the technique more commonly known in this literature as śāmbhavì mudrā. Unlike other Hatha- and Rājayoga texts, the Yogatārāvalī concludes with a somewhat poetic description of the yogin abiding in the complete stillness of samādhi:

Oh! When the sun of the supreme self is shining and the darkness of all ignorance is disappearing, wise men, though their sight is untainted, see nothing whatsoever of the multiplicity of the world. In caves on the peak of Sriśaila [mountain], when will I experience samādhi's culmination in which dissolution of the mind is such that vines cover my body and birds build a nest in my ear? ${ }^{16}$

Liberation is not mentioned explicitly in the Yogatārāvalī. The following verse, which may have been added later to the text, ${ }^{17}$ further suggests that the yogin is liberated-in-life:

Let this mind [of mine] wander into thoughtless samädhi or into the plump breasts of [women] whose eyes are [as alluring as those of] the spotted black

14 These manuscripts are Ms No. 75278, Adyar Research Library, Ms No. 240-3748, Ānandāśramasamsthā and Ms. No. 412, Panjab University Library Lahore, which omit verses 22, 26, and 29 of the Vārāṇāseya Saṃskṛta Saṃsthāna edition. These verses are included in other editions and manuscripts but their numbering may differ.

15 Two important manuscripts (i.e. Ms No. P5682/3 Mysore Oriental Research Institute; Ms No. 18/2 Sringeri Sharada Peetham) insert headings and colophons which indicate that verses $2-5$ concern Layayoga and 6-13, Hathayoga. Although this is plausible, the Yogatärāvali does not refer to Layayoga. If one ignores these headings, it is possible that verses 2-5 are describing the fusion of the mind with the resonance (nādānusandhāna) which is achieved by the practice of kumbhakas, explained by verses $6-13$, in which there is a reference to Hathayoga.

${ }^{16}$ Yogatārāvali 27-8 (prakāśamāne paramätmabhānau naśyaty avidyātimire samaste|aho budhā nirmaladṛștayo 'pi kiñ cin na paśyanti jagatprapañcam || siddhị̣ tathāvidhamanovilayām samādheh śríśailaśrńgakuhareșu kadopalapsye | gātram yathā mama latāh pariveșțayanti karṇe yathā viracayanti khagāś ca nìdam).

17 See footnote 15. 
deer. Let it do ceaseless repetition of a mantra or likewise small talk. The merits and faults produced by thought do not touch me, the all-pervading [self]. ${ }^{18}$

The culmination of the Yogatārāvalìs teachings is complete transcendence of the world and mind. The outcome is not orientated towards attaining power (siddhi) in the world. The reference to an 'all-pervading' self (vibhu), which is untouched by thought, merit, and so on, merely reflects the vedāntic undertones of this version of the text. It is possible that the original work finished with the yogin enveloped by creepers in a cave and left open the question of whether he emerged to act in the world.

\subsection{The Amanaska (Second Chapter)}

The Amanaska ('the no-mind state') consists of two chapters, which were probably composed separately in different centuries and combined sometime before the eighteenth century. ${ }^{19}$ The second chapter, which is the older of the two and teaches a system of Rajjayoga, predates the twelfth-century Jain scholar Hemacandra (Birch 2014: n. 21). The available printed editions present a redaction of the text that was probably made in South India sometime after the fifteenth century. There is considerable manuscript evidence for a shorter redaction which predates the South Indian one and was prevalent in North India and, more recently, Nepal (Birch 2013).

The second chapter of the shorter redaction begins with Vāmadeva asking Śiva to teach him the advanced yoga that should follow the preliminary one he has learned. Siva replies that the advanced yoga is called Rajjayoga, ${ }^{20}$ and it is made clear early in this chapter that the main technique of Rājayoga, namely śämbhavi

\footnotetext{
18 Yogatārāvalī 29 (vicaratu matir eșā nirvikalpe samādhau kucakalaśayuge vā kṛ̣nasārekṣaṇānām| caratu japam ajasrạ̣ jalpam alpaṃ samạ̣ vā matikṛtagunadoșā māṃ vibhuṃ na spréśanti).

19 The earliest dated manuscript known to me that has both chapters and the name Amanaska is at the Sanskrit University Library (Sarasvati Bhavana), Varanasi (Ms No. 30111). It is dated samvat 1778 sare 'smin vaiśäkhamāse krșnapakșe saptamyām bhṛuvāre, which is $18.4 .1721 \mathrm{CE}$. The earliest text to quote verses from both chapters with attribution to the Amanaska is the Goraksasiddhantasangraha, which may date to the nineteenth century (Birch 2013: 165-6). The terminus ad quem of the Amanaska's first chapter is Śivānandasarasvatīs Yogacintāmaṇi, which was composed in the late sixteenth or early seventeenth century (Birch 2014: 403).

${ }^{20}$ Amanaska 1-3ab: "Vāmadeva said, "O Lord, chief god of gods, [you] who are beautiful because of [your] supreme bliss, I have obtained the extensive preliminary yoga by your favour. Tell [me] about that other [yoga] which was mentioned by your lordship." Siva replied, “The preliminary [yoga] is furnished with external mudrās and [thus] it is regarded as an external yoga. [Whereas] the other [yoga] is richly endowed with an internal mudrā [and] for that reason, it alone is the internal yoga. The [internal yoga] is called Rājayoga. O chief of sages."' (vāmadeva uvāca | bhagavan devadeveśa paramānandasundara | tvatprasādān mayā labdhah pūrvayogah savistarah | aparam kị̣ tad ākhyāhi bhavatā yad udìritam ||1|| ìśvara uvāca | bahirmudrānvitạ̣ pūrvam bahiryogam ca tan matam | antarmudrädhyam aparam antaryogam tad eva hi $\|2\|$ räjayogah sa kathitah sa eva munipungava).
} 
$m u d r \bar{a}$, bestows liberation-in-life. ${ }^{21}$ The simple assumption behind the practice of this mudrā is that liberation arises when both the mind and breath disappear. The following verse succinctly states this:

Therefore, having abandoned all sense objects because of meditation on an aspectless self, the breath disappears, then the mind and, because of the disappearance of that, liberation arises. $\mathrm{O}$ adepts, having realised this, first and foremost make an effort to accomplish the no-mind state, which is natural, pure, aspectless and unchanging. ${ }^{22}$

Liberation is contrasted with transmigration (samsāra) in the same terms. The former arises when the mind is still and the latter when the mind is moving. ${ }^{23}$ The text pursues this idea to its logical conclusion, that being that the yogin in samādhi is liberated: ${ }^{24}$

[The Rajjayogin] who always remains as though asleep in the state of waking and is free from breathing in and out, is certainly liberated. ${ }^{25}$

The Amanaska does not teach yogic suicide (utkrānti) nor does it mention a transformative process after the no-mind state has been attained. ${ }^{26}$ The question of whether the yogin engages with the world after liberation is answered towards the end of the text:

For one who is thus [well absorbed ${ }^{27}$, meritorious and unmeritorious actions are completely destroyed. When those actions are being performed by such a sage, they do not taint him at all. The wise person in whom the bliss of the

${ }^{21}$ Amanaska 2.15: '[Just as Arjuna's] fist [aimed his bow] upwards [at the yantra], [yet] his gaze was [on Rādhäs reflection in a bowl of oil] below; his piercing [of the target] was above, [yet] his head was [tilted] down, [just so the yogin practises śämbhavī mudrā.] He will become liberated-in-life by [this] method of [gazing down at] Rādhā and [aiming upwards at the] yantra' (ūrdhvamuștir adhodrsștir $\bar{u}$ rdhvavedhas tv adhahśsirāh | rädhāyantravidhānena jīvanmukto bhavișyati).

${ }^{22}$ Amanaska 2.41 (tasmāt tyaktvā sakalavișayān niṣkalādhyātmayogād vayor nāśas tadanu manasas tadvināśāc ca mokṣah | sañcintyaivam sahajam amalạ̣ niṣkalạ̣ nirvikāram prāptum yatnaṃ kuruta kuśalāh pūrvam evāmanaskam).

${ }^{23}$ Amanaska 2.92 (citte calati samsāro 'cale mokṣah prajāyate | tasmāc cittam sthirīkuryād audāsīnyaparāyaṇah). Cf. Devīkālottara 10 and Śivayogaratna 3 (citte calati saṃāro niścale mokṣa eva tu| tasmāc cittam sthiram kuryāt prajñayā parayā budhah).

${ }^{24}$ For these qualifications of the no-mind state, see Amanaska 2.41, 77, 110.

${ }^{25}$ Amanaska 2.59, 60cd, 62 (sadā jāgradavasthāyām suptavad yo 'vatișțhate| niśvāsocchvāsahīnaś ca niścitam mukta eva sah).

${ }^{26}$ This contrasts with the first chapter of the Amanaska (probably composed in the late fifteenth or early sixteenth century). The end of the first chapter states that the yogin spends twenty-four years in samādhi, at which time he remains absorbed in the Śakti element, sees the entire world as a pearl in his hand, and truly knows the essential nature of his own body (1.82-3). The teachings of the first chapter are prompted by Vāmadeva asking Śiva for a means to liberation-in-life (jīvanmukti).

${ }_{27}$ The previous two verses (2.98-9) describe the highest stage of yoga called 'well-absorbed' (suślișța). 
natural [no-mind state] has emerged, who is naturally devoted to constant practice and who has completely freed himself of all volition, relinquishes action. ${ }^{28}$

The liberated yogin, as conceived by the Amanaska, remains free of intention (sankalpa) and action, because of his constant practice of yoga (sadābhyāsa). Thus, even if he were to do something, he remains free of karmic effects (karmatyāga). The text's emphasis on a liberation free from action and cognition, with the exception of bliss $(2.97-8,100)$, is further reinforced by the theme of detachment (audāsinya), which is prescribed for the practice $(2.52,54)$ and continues in the no-mind state (2.80).

\subsection{The Gorakșaśataka}

The yoga of the Gorakșaśataka aims at liberation from the world (bhavamukti) through gnostic realizations about the body and universe, which occur after the attainment of samādhi by the conquest of the breath (marujjaya) and the raising of kundalinī. ${ }^{29}$ The breath is conquered by adopting a moderate diet (mitāhāra), a yogic posture (āsana), and moving kundalinī (śakticāla) (11). The text does not refer to Hațha- or Rajjayoga, but it is the earliest known text to teach four of the Hathapradīpikä's eight breath retentions (kumbhaka). ${ }^{30}$ The Goraksaśataka's description of samädhi is very brief. It simply says:

Now, I shall teach the best method for samädhi (samädhikrama), which is deathdestroying and a means to [transcendental] happiness. It always brings about the bliss of Brahman. ${ }^{31}$

The 'best method' referred to here is stimulating sarasvati (i.e. kundalinī) by manipulating the tongue with a cloth (sarasvaticalana) and performing the kumbhakas with the three internal locks (bandha) (51ab). The kumbhakas are supposed to move the breath into the central channel (63ab) and raise kundalinī (75).

The connection between samädhi and liberation is not stated explicitly in the Gorakșaśataka. However, one might infer from the following description of the

\footnotetext{
${ }^{28}$ Amanaska 2.99-100 (evaṃbhūtasya karmāṇi punyāpunyāni saṃkṣayam | prayānti naiva limpanti kriyamānāni sādhunā || utpannasahajānandah sadābhyāsaratah svayam | sarvasañkalpasamtyaktah sa vidvān karma saṃtyajet).

29 The Gorakșaśataka being discussed here has 101 verses. It is different to another yoga text of the same name, which has nearly 200 verses that are similar to those of the Vivekamärtanda. See Bouy 1994: 40-1.

${ }^{30}$ These kumbhakas are called sūryā, ujjāy $\bar{\imath}$, sìtalī and bhastrī.

31 Gorakșaśataka 63cd-64ab (athedānīm pravakșāmi samādhikramam uttamam | mrityughnam sukhadopāyam brahmānandakaram sadā).
} 
liberated yogin that he is in a state of samädhi, because it is similar to accounts of samādhi in other yoga texts of this corpus:

He is indeed liberated whose mind is at rest because of yoga, not awake, asleep or in any other [state] and does not cease or arise. One whose breath does not flow in or out; does not move in the left or right [nostril] and does not go up or down, is undoubtedly liberated. There are two causes of the mind: a past impression $(v \bar{a} s a n \bar{a})$ and the breath. When one of the two disappears, then both also disappear. Therefore, conquer the breath first. Thus, a man who is bound is liberated and is freed from old age and so on. ${ }^{32}$

The Gorakșaśataka does not use the term jīvanmukti. However, its last twelve verses, which have been poorly preserved by the two available manuscripts, appear to describe seven levels of liberating gnosis, without mentioning any siddhis. The conclusion does not suggest that the yogin casts off his body, but remains alive in a gnostic state.

\subsection{The Vasișthasaṃitā and the Yogayājñavalkya}

The Vasișthasaṃitā and the Yogayājñavalkya can be discussed together, because the former was the source of much of the latter's content. In fact, the Yogayajjnavalkya borrows over 250 of its verses from the first four chapters of the Vasișthasaṃitā (2005: 28) and simply adds some additional passages. Both works teach a very similar type of aștāigayoga that derives from earlier Vaiṣnava works, in particular the Vimānārcanākalpa (Mallinson 2014: 227-8), a Vaikhanāsa work that may date to the ninth century (Colas 2003: 158). Also, the yoga of the Vasișthasamhitā and the Yogayajjñavalkya is similar in content and style to that of the Sütasam itta $^{33}$ and some Pāñcarātrika texts, such as the Ahirbudhnyasaṃhitā. Sometime between the thirteenth and fifteenth century, it appears that this astângayoga was combined with the ten mudrās of Kapila to form a system of Hathayoga, as evinced in the Dattātreyayogaśāstra (29). However, neither the Vasișthasaṃitā nor the Yogayajjñavalkya refer to their yoga as Hatha- or Rājayoga.

The current version of the Vasișthasaṃhitā has eight chapters. The first four appear to have been either the earliest layer of the current text, to which the

\footnotetext{
32 Gorakșaśataka 7-10 (cittam prasuptam yogena jāgrat suptam na cānyathā | nāstam eti na codeti yasyāsau mukta eva hi $\|7\|$ praveśe nirgame vāme dakșine cordhvam apy adhah | na yasya vāyur vahati sa mukto nātra samíayah ||8|| hetudvayam ca cittasya vāsanā ca samīranah | tayor vinașta ekasmims tad dvāv api vinaśyatah $\|9\|$ tasmād ādau samìrasya vijayam kuru samyutah | yas tv evam puruṣo mukto bhaven mukto jarādibhih $\|10\|$. Cf. Mokṣopāya 5.92 .48 (dve bīje rāma cittasya prānaspandanavāsane | ekasmiṃś ca tayor nașțe kșiprạ̣ dve api naśyatah).

${ }^{33}$ See chapters $12-20$ of the jũannayogakhanda in the Sütasamhitā.
} 
other chapters were added at a later time, or a different work with which the other chapters were combined to create the Vasisthasamhitā. ${ }^{34}$ The first four chapters appear to have been composed by Vaịnnava Smārta Brahmins, whereas the other chapters may derive from Śaiva sources. ${ }^{35}$

The Vasișthasaṃhitā (1.24-31) and the Yogayajjñavalkya (1.24-44) present aștāingayoga as an auxiliary to internal gnostic daily rites (nityakarma). Following the injunctions of the Vedas, both texts enjoin the performance of daily rites for attaining liberation, but divide them into external and internal rites. The internal rite is a contemplative practice that should be accompanied by knowledge (jñāna), which is later defined as aștāingayoga:

The internal [rite] is a practice according to [Vedic] rule [done] with only the intellect on the self [...]. O learned Brahmin, since even gnostics desirous of liberation do rites, you also should perform these rites with knowledge. [...] Know that [this] knowledge is essentially yoga and yoga is located in oneself. This yoga is endowed with eight auxiliaries and it is said to be a religion for all. ${ }^{36}$

The Vasișthasaṃhitā and the Yogayajjñavalkya claim that liberation-in-life (jīvanmukti) can be achieved by the practice of yoga. ${ }^{37}$ Samädhi is discussed at length because the system of aștaningayoga culminates in it. However, in the section on meditation (dhyāna), an interesting distinction between liberation-in-life and permanent liberation is suggested:

After a year [of visualizing nectar in meditation], one is without doubt liberated while living. One liberated-in-life never incurs suffering at any place. What

\footnotetext{
34 The fact that the main topic of the Vasisțhasamhitä’s first four chapters is a Vaișnava version of astāingayoga and that the fourth chapter concludes with verses proclaiming the merits of reading the text indicates that these chapters were written as a unit. The remaining chapters introduce new topics, namely, knowing the time of death (nāśakāla), overcoming death by means of samādhi, seeing auspicious and inauspicious results and the time of death at equinoctial and solstitial points (ayana), and signs (cihna) of death.

${ }^{35}$ The Vaișnava background of this aștañngayoga is revealed by references to Viṣnu (e.g. Vasiṣthasaṃità 1.11-1.12 Yogayājñavalkya 1.12-1.13, 12.45-12.46), visualization practices on Viṣnu (e.g. Vasișthasaṃhitā 4.27-4.38, Yogayājñavalkya 9.13-9.23), etc., as well as the Vaiṣnava textual sources from which it is adapted (mentioned above). The Smārta element is the Vedic framing of the teachings in the first chapter of both works, references on caste and position in life (varnāśrama) (e.g. Vasișthasaṃitā 1.20-1.25, Yogayajjñavalkya 1.21-1.25), the importance of performing Vedic rites with gnosis (see below), etc. The Saiva orientation of the sixth chapter is indicated by the mention of Rudra and the recitation of the tryambaka verse in various methods for conquering death. I would like to thank Lubomír Ondračka for bringing this Śaiva influence in the Vasișthasaṃhitā to my attention.

${ }^{36}$ Vasișthasaṃhitā 1.23cd, 27, 1.31 (äbhyantaram tu buddhyaiva vidhyānușthānam àtmani || yatah karmaiva kurvanti jñānino 'pi mumukșavah | tatas tvam api viprendra jñānenācara karma tat || [...] jñānaṃ yogātmakạ̣ viddhi yogaś cātmani tișthati | sa yogo ștāng gasamyuktah sarvadharmah sa ucyate ||123d vidhy- ] mss. ra, la, śa, buddhy- ed). Cf. Yogayajjñavalkya 1.39 and 1.44 .

37 The term jīvanmukta is mentioned at Vasișthasaṃhitā $4.14 \mathrm{~d}$ and $4.47 \mathrm{a}$ and Yogayaj ñavalkya 9.41a.
} 
more [can be said] of one permanently liberated (nityamukta)? For this reason, liberation [proper] is difficult to obtain. Therefore, O learned Brahmin, for attaining liberation follow my teaching and do daily rites, which are void of rewards, in conjunction with knowledge (i.e., aștāingayoga). ${ }^{38}$

This statement implies that liberation-in-life was not thought to be permanent in this tradition. The notion of two types of liberation is somewhat similar to attempts by some Vedāntin philosophers to distinguish between liberation-inlife and liberation at death, the latter of which is sometimes said to be more complete because all karma is exhausted. ${ }^{39}$ In the Vasisthasamhitā and the Yogayajjnavalkya, the concept of a permanent liberation implies that the yogin must continue to perform daily rites or, in this case, yoga, even when liberatedin-life. The twofold liberation, as well as the defining of yoga as a form of daily ritual, appears to have been contrived to defend Brahmin householders from accusations that they were transgressing the Vedas by not doing daily rites when engaged in the practice of yoga and inactive states of meditation. In the following passage, the Yogayajjnavalkya addresses this point more explicitly than the Vasișthasamhitā:

Gārgi asked, "O lord, how can a man engaged in yoga perform his vedic rites regularly or at the junctures of the day? What is the expiation for one not doing them?” [...] Yājñavalkya replied, "O Gārgi, for a man engaged in yoga, the rites that should be done at the junctures of the day or at night have been accomplished by his yoga [practice]. When his own [internal] fire of the agnihotra rite is ignited by breath retentions, what expiation is needed by [such a yogin,] who is offering rites as taught by vedic injunction with his purified mind as the oblation, $\mathrm{O}$ child? Then, indeed, he is one who has performed his rites. When separation (viyoga) of the individual self with the supreme self is experienced, knowers of Brahman should regularly perform rites as taught by vedic injunction. At the time of separation, the yogin who abandons his rites, thinking it is only suffering, his resting place is hell. Since people cannot abandon their rites entirely, yogins should always perform their vedic rites until death. O Gārgi, do not be one who has transgressed. Perform your vedic rites." ${ }^{40}$

38 Vasișṭhasaṃhitā 4.46cd-48 (vatsarān mukta eva syāj jīvann eva na saṃśayah || jīvanmuktasya na kvāpi duḥkhāvāptih kadācana | kị̣ punar nityamuktasya tasmān muktir hi durlabhā || tasmāt tvam api viprendra muktaye kuru madvacah | jñānena saha karmāṇi phalaśūnyāni nityaśah). Cf. Yogayäjñavalkya 9.41.

${ }_{39}$ For example, Sānkkyapravacanabhāşya 1.1 (of Vijñānabhikṣu): 'The respective difference is that, in the state of liberation-in-life, latent states of suffering called seeds are burnt except for the consequences of [currently] activated karma (prärabdhakarma), whereas in bodiless liberation it is [all] destroyed along with the mind' (jīvanmuktidaśāyām ca prārabdhakarmaphalätiriktānām duḥhhānām anāgatāvasthānām bìjākhyānām dāho, videhakaivalye tu cittena saha vināśa ity avāntaraviśeșah).

${ }^{40}$ Yogayājñavalkya $11.211 .4-11.9$ (gārgy uvāca | yogayukto narah svāmin sandhyayor vāthavā sadā | vaidhạ̣ karma katham kuryān niṣkṛtih kā tv akurvatah || yājñavalkya uvāca | yogayuktamanuşyasya sandhyayor vāthavā niśi | yat kartavyam varārohe yogena khalu tat kṛtam || àtmāgnihotravahnau tu 


\subsection{The Amrtasiddhi}

The Amrtasiddhi does not call its system of yoga Hațha- or Rājayoga. Nonetheless, it is the earliest known textual source on three physical mudrās, namely mahāmudrā, mahābandha, and mahāvedha, which became important techniques in nearly all medieval systems of Hathayoga. The Amrtasiddhi also contains detailed descriptions of certain theoretical notions, such as a store of semen in the head being slowly consumed by the fire of the abdomen and the interdependence of semen, mind, and breath, that are mentioned in many subsequent yoga texts (Mallinson 2016a: 6). However, much of its detailed and somewhat eccentric hybrid doctrine, which appears to have been intended for esoteric Buddhists who had rejected deity yoga (Szántó 2016), is absent in Hațha- and Rājayoga texts. The Amṛtasiddhi contains chapters on samädhi and jìvanmukti, the latter term being extremely rare in Buddhist works, ${ }^{41}$ despite it occurring in Śaiva and vedāntic works of the same era. ${ }^{42}$

The chapter on samädhi immediately follows a chapter on the mastery of the breath (väyusiddhi), in which the breath becomes still when the sound of a drum (mardala) arises in the central channel (25.2). This causes samädhi, which is described as follows:

[When] that breath is full of perfection and motionless in the central channel, then the mind becomes full of bliss and uniform like the sky. When the mind is full of bliss and is free from external afflictions, sufferings of the world are extinguished and samādhi then arises. ${ }^{43}$

According to the next chapter, the attainment of samādhi prefects the mind:

When the mind is refined by samädhi and full of natural bliss, then it is perfected and destroys all suffering and fear. ${ }^{44}$

prānāyāmair vivardhite | viśuddhacittahavișā vidhyuktam karma juhvatah || niṣkrtis tasya kiṃ bāle krtakrtyas tadā khalu | viyoge sati samprāpte jīvātmaparamātmanoh || vidhyuktạ̣ karma kartavyam brahmavidbhiś ca nityaśah | viyogakāle yogī ca duhkham ity eva yas tyajet || karmāni tasya nilayah nirayah parikīrtitah | na dehinām yatah śakyam tyaktum karmāny aśeșatah || tasmād ā maranāàd vaidham kartavyạ̣ yogibhị sad̄̄| tvaṃ caiva mātyayā gārgi vaidham karma samācara).

41 I am aware of references to jīvanmukti (or - mukta) in only two works relevant to Buddhism. The first is the Vādarasāvalī of Vindhyavāsī and the second is the Śrīmitra inscription (1183-92 CE). I wish to thank Péter-Dániel Szántó for informing me of these references. Schaeffer (2002: 521-2) notes the peculiarities of the Amrtasiddhi's psychophysical realization (i.e. jivanmukti) and says that the Amrtasiddhi is the 'only work transmitted to Tibet that I yet know of which develops this characteristically un-Buddhist notion of liberation'.

${ }^{42}$ For references to jīvanmukti in such works, see L. Bansat-Boudon (2013), O.S. Saraogi (2010), W. Slaje (2000a), etc.

43 Amrtasiddhi 26.1-2 (yo ['] sau siddhimayo vāyur madhyamāpadaniścalah || tadānandamayam cittam ekarūpam nabhahsamam || yadānandamayạ̣ cittam bāhyakleśavivarjitam || bhavaduhkhāni saṃhṛtya samādhir jāyate tadā \| iti samādhivivekah).

${ }_{44}$ Amṛtasiddhi 27.1 (yadāsamādhisampannam sahajānandasaṃbhurtam | cittam eva tadā siddham sarvaduḥkhabhayāpaham \| iti siddhacittavivekah). 
The Amrtasiddhi's chapter on liberation-in-life begins with the piercing of Rudra's knot (granthi), which moves the breath to Siva's throne located between the eyebrows (30.1 ab). ${ }^{45}$ The yogin's body, speech, and mind are perfected, culminating in the attainment of the great siddhi that bestows the reward of liberation-in-life (30.3), as well as various other siddhis. The liberated yogin is said to be all-knowing (sarvajña), all-seeing (sarvadarśin), and so on, as well as having all eight lordly powers (sarvaiśvaryagunopeta). In other words, this liberated state is characterized by the power to know and do anything, including helping others achieve liberation. ${ }^{46}$ Nonetheless, the chapter concludes by saying the following:

Wandering through the cycle of samsāra, which is the cage of the three worlds, the yogin, having easily broken [this cycle], becomes powerful and full of bliss. In this way, perfected yogins play on mountain peaks and in caves for hundreds, thousands and [even] hundreds of thousands of years. Indifferent to knowledge of the external world and devoted to samädhi, these yogins, who see with gnosis, remain in a place free of people. They live thus and are seen doing what has to be done. These yogins, who are perfected in the form of victors (jina), should be known as liberated-in-life. ${ }^{47}$

The Amrtasiddhi's conception of the liberated yogin melds the idea of an allpowerful being, who enjoys the world, with the transcendent notion of a yogin who is indifferent to the world and devoted to samädhi and a secluded life. A subsequent verse states that the liberated yogin should use his power to make his body invisible. ${ }^{48}$ Such a view of the body, which was also adopted by the author of the Yogabija, appears to be the logical outcome of achieving embodied immortality and complete transcendence over materiality. The notion of invisible siddhas in caves and on mountain peaks is an early precursor of more recent myths of ancient $s \bar{a} d h u s$ living in the Himalayas, who allegedly reveal themselves to only genuine seekers. ${ }^{49}$

${ }^{45}$ Amrtasiddhi 30.1ab (rudragranthim tadā bhittvā pavanah śarvapịthagah | śarva- ] emend.: sarvaEd.). Cf. Hațhapradīpikā 4.76. The Jyotsnā (4.76) locates śarvapițha between the eyebrows ([...] śarvasyeśvarasya pịtham sthānam bhrūmadhyam [...]).

46 Amrtasiddhi 31.10a: 'Content, he helps people cross over' (samtuștas tārayel lokān).

${ }^{47}$ Amṛtasiddhi 31.11-14 (bhraman sāmsārikam cakram bhuvanatrayapañjaram || tad bhittvā helayā yogī yāty ānandamayo vibhuh | evaṃ varșasahasrāni lakṣāni ca śatāni ca | parvatāgre guhāyām ca krìdanti siddhayoginah || viraktā bāhyavijñāne raktāh samādhimadhyatah | tișthanti vijane sthāne yogino jñānacakṣuṣah || evambhūtāś ca tiṣthanti drśsyante kāryaśālinah | jīvanmuktāś ca te jñeyā ye siddhā jinarūpinah || iti jīvanmuktilakșanavivekah).

48 Amrtasiddhi 34.3: 'The holder of yoga, who has been perfected thus by samädhi and delighted by the three blisses, should make his body invisible by his power' (evam samädhisampanna ānandatrayananditah | śarīragopanam kuryād aiśvaryeṇa ca yogadhṛk).

${ }^{49}$ For example, Autobiography of a Yogi by Paramahamsa Yogananda (1946), Living with the Himalayan Masters by Swami Rama and Swami Ajaya (1978), etc. This myth is also found in theosophical works, such as The Masters and the Path by C.W. Leadbeater (1925), and it appears to have inspired the formation of the esoteric sub-branch of the Theosophical Society called 'The Himalayan School of Adepts' in the 1880s. 


\subsection{The Amaraughaprabodha}

Recently discovered manuscript evidence has revealed that there are two recensions of the Amaraughaprabodha (Birch 2019). Kalyani Mallik's (1954) published edition of the Amaraughaprabodha, which was based on one manuscript (1954: 34), presents a long recension of seventy-five verses. Two unpublished manuscripts preserve a shorter one of forty-six verses. ${ }^{50}$ The short recension is the older of the two and may be one of the earliest works, probably predating the Dattātreyayogaśāstra, to teach the combination of Hatha- and Rajjayoga (Birch 2019: 26). In fact, both recensions have a system of four yogas: Mantra-, Laya-, Hatha-, and Rājayoga. They are defined succinctly in the following shared verse:

Laya is taught as that [yoga] which is a constant flow of mental activity [on the deity ${ }^{51}$ ] and Hatha is that [yoga] which is accomplished by the breath and internal resonance. Mantrayoga is that [practice] which controls the mantra-body [of a deity]. Rājayoga is that [state] which is free of mental activity. ${ }^{52}$

Rajayoga is the goal of the first three yogas (see below). It is also described as beyond the state of duality, ${ }^{53}$ an abode of awakening and full of eternal bliss. ${ }^{54}$ Rajayoga is clearly the main concern of the Amaraughaprabodha, because the term amaraugha is said to be a synonym of Rajjayoga. ${ }^{55}$ Amaraugha is also redolent of the divyaugha, a divine stream of teachings mentioned in earlier Kaula scriptures. ${ }^{56}$ The claim encoded in the term amaraugha, that it transmits the highest teachings emanating from Śiva, may have been intended to conceal the fact that its system of Hathayoga was largely derived from the yoga of a Vajrayāna tradition, which was recorded in the Amrtasiddhi. ${ }^{57}$

${ }^{50}$ Manuscripts 1448 (GOML) and 70,528 (Adyar) preserve the short recension of the Amaraughaprabodha and four other manuscripts, namely 4340 (GOML), 75,278 (Adyar), 7970 (Baroda), and 179a (Tirupati), the long one. For further details, see Birch 2019.

${ }^{51}$ In other yoga texts, Layayoga is defined as the dissolution of mental activity (e.g. Dattātreyayogaśástra 15, Yogabija 150cd-151ab, etc.). However, the section on Layayoga in the Amaraughaprabodha (19-20) describes it as the meditation practice of visualizing Siva.

${ }^{52}$ Amaraughaprabodha 3 (yaś cittasantatagatih sa layah pradișto yaś ca prabhañjananinādakṛto hațah sah | yo mantramūrtivaśagah sa tu mantrayogo yaś cittavrttirahitah sa tu rājayogah).

53 Amaraughaprabodha 2cd (caturtho rājayogaś ca dvidhābhàvvavivarjitah).

${ }^{54}$ Amaraughaprabodha 6cd literally says, 'Even after the various practices of yogins, the breath does not go into the base [of the torso] without the respected Rajjayoga, which is an abode of awakening and full of eternal bliss' (ādhāre pavano na yāti vividhād abhyāsato yoginām nityānandamayāt prabodhanilayāc chrīrājayogād ṛte).

${ }^{55}$ Amaraughaprabodha 17ab: 'For, this unique amaraugha alone is called Rajjayoga' (eka evāmaraugho hi rājayogābhidhānakah).

${ }^{56}$ I am grateful to Somadeva Vasudeva for pointing this out to me. For more information on divyaugha, see the Täntrikābhidhānakośa vol. 3 (2013: 168).

57 The Amaraughaprabodha's section on Hathayoga borrows several verses on its main techniques from the Amrtasiddhi (Mallinson 2016a: 113). 
In the Amaraughaprabodha, Rajjayoga is described as uniting the mind with a flute-like sound. In the short redaction, the main section on Rajayoga is at the end of the text:

When the mind has become one [with the flute-like sound], then it is called Rajjayoga. [The yogin] becomes a creator and destroyer [of the universe] and an equal to the god of yogins. [In Rājayoga] there is no resonance, no bondage, no consciousness nor even unconsciousness [and so] there is no subsequent practice whatsoever. [This state] is called Rājayoga. [For the Rajjayogin,] that into which the universe is easily dissolved is called [Śiva's] linga. The power of consciousness, which is difficult to understand because of its unfathomable form, has the radiance of the three worlds. Gnosis is that which removes all obstacles of wealth, sense objects and world interaction. [And] mind is that which playfully destroys the veil of unlimited time. ${ }^{58}$

The short recension adds only two verses to the above passage, one of which claims that the four yogas were taught by the honourable Gorakșanātha, who is always abiding in samādhi (amaraugha), for the sole attainment of Rājayoga. ${ }^{59}$ Although liberation is not mentioned explicitly, the final impression is that of a liberated yogin continuing to live in Rajjayoga with the power of Siva. His immortality is affirmed by earlier references in the text $(10,14,24,32$, etc.), so it is clear that liberation-in-life was intended. In fact, immortality is implied by the term amaraugha, which can mean the 'tradition of immortals (amara)'.

\subsection{The Dattātreyayogaśāstra}

The Dattātreyayogaśāstra teaches the same system of four yogas as the Amaraughaprabodha (i.e. Mantra-, Laya-, Haṭha-, and Rajjayoga), the last of which is said to be the best (10). ${ }^{60}$ The Dattātreyayogaśāstra's Laya- and Hathayoga bring together a much larger repertoire of techniques than those of the Amrtasiddhi and the Amaraughaprabodha. Its Rājayoga is said to arise as a result of practising the other yogas:

\footnotetext{
58 Amaraughaprabodha 44-6 (ekībhūtaṃ tadā cittam rājayogābhidhānakam | șṛțisaṃhārakartāsau yogeśvarasamo bhavet ||44|| na nādo na ca bandhaś ca na cittạ̣ nāpy acetanam | nābhyāsam uttaram kiñ cit rājayogo nigadyate ||45|| linnam yatra carācaram sukhavaśāt tal lingam ity ucyate sā cicchaktir acintyarūpagahanā lokatrayodbhāsin̄i | taj jñānam yad aśeșavastuvișayavyāpāravārāpaham tac cittam yad asimakālapațalapradhvamsanam helayā $\| 46||$. I would like to thank Dominic Goodall, Diwakar Acharya, and Gavin Flood for their comments on these verses.

59 Amaraughaprabodha 47 (śrimmadgorakṣanāthena sadāmaraughavartinā || layamantrahațhāh proktā rājayogāya kevalaṃ).

${ }^{60}$ See section 2.
} 
With all these [techniques of Mantra, Laya, and Hatha], one should practice [yoga] at the appropriate time. Then, Rājayoga arises and certainly not otherwise. Success does not arise through mere theory, but by practice alone. Having obtained the supreme [state of] Rājayoga, which subjugates all beings, [the yogin] can do anything or nothing, acting as he desires. ${ }^{61}$

The liberation offered by the Dattātreyayogaśāstra is clearly liberation-in-life (jivanmukti), which is mentioned in a passage on the practice of a formless meditation that leads to samādhi:

Within only twelve days [of practising formless meditation], one can achieve samādhi. Having stopped the breath, the wise person is surely liberated-in-life. Samādhi is the state of sameness of the individual self with the supreme self. ${ }^{62}$

Unlike other works in this corpus, the Dattātreyayogaśāstra describes the choice that arises for the liberated yogin at some point in samädhi:

If [the yogin] has the desire to cast off his body and if he does so naturally, he dissolves into the supreme Brahman, having abandoned [all] action, good and bad. And if his own body is dear to him and he desires not to cast it off, he can wander in all the worlds, endowed with the siddhis beginning with minimisation. Having become a god whenever he desires it, he could also live in heaven. Or he may instantly become either a man or a spirit by his own wish. He may become a creature, by his wish, a lion, tiger, elephant or horse. Thus, by his will, the wise yogin lives as a great god. ${ }^{63}$

While seeming to acknowledge the dichotomy of a disembodied and embodied liberation, the Dattātreyayogaśāstra attempts to reconcile the two by presenting them as a choice. Embodied liberation is framed as a transformation into an allpowerful, shape-shifting god, who presumably remains free from the consequences of his actions. This theistic liberation, so to speak, overshadows a suspicion the author has towards siddhis in the case of one who is not liberated. The following comment is made earlier in the text after a passage describing the siddhis attained by the practice of prānāyāma:

${ }^{61}$ Dattātreyayogaśāstra 159cd-161 (etaih sarvais tu kathitair abhyaset kālakālatah || tato bhaved rājayogo nāntarā bhavati dhruvam | na dinmātreṇa siddhih syād abhyāsenaiva jāyate || rājayogavaram prāpya sarvasattvavaśaṃkaram | sarvam kuryān na vā kuryād yathäruciviceștitam).

${ }_{62}$ Dattātreyayogaśāstra 125-126ab (dinadvādaśakenaiva samādhim samavāpnuyāt | vāyum nirudhya medhāvī jīvanmukto bhaved dhruvam ||125|| samādhi h samatāvasthā jīvātmaparamātmanoh).

${ }^{63}$ Dattātreyayogaśāstra 127-130ab (yadi syād deham utsrașțum icchā ced utsrịet svayam | atha cen no samutsraștum svaśarīram yadi priyam || sarvalokeșu vicared animādigunānvitah | kadā cit svecchayā devo bhūtvā svarge 'pi samcaret || manuşyo vāpi yakșo vā svecchayā hi kṣaṇād bhavet | siṃho vyāghro gajo vāśvaḥ icchayā jantutām vrajet || yatheșțam evạ̣ varteta yogī vidvān maheśvarah). 
These [siddhis] are obstacles to the great accomplishment [of liberation]. The wise [yogin] should not delight in them, and he should never show his power to anyone. He should behave among people as a dumb, stupid or deaf person, in order to keep his power secret. ${ }^{64}$

\subsection{The Yogabija}

The Yogabija is a dialogue between Śiva (î́śvara) and Devī that teaches Rājayoga as the culmination of the same fourfold system of yoga as the Amaraughaprabodha and the Dattātreyayogaśāstra. The printed editions present a late recension of the work that predates the Yogacintāmani (seventeenth century) and has nearly thirty additional verses, including the well-known definition of hatha as the union of the sun and moon, which are not in an earlier recension. ${ }^{65}$ The following discussion is based on passages in the earlier recension, which has not been published but is preserved by two manuscripts. ${ }^{66}$

Unlike other Hatha- and Rājayoga texts, the Yogabija argues that both gnosis and yoga are needed for liberation. Devī plays the role of the contentious inquisitor and asks at one point whether yoga is necessary at all for liberation:

Because of ignorance alone, there is transmigration and because of knowledge alone, one is freed. Therefore, tell me clearly what can be accomplished by yoga in this regard? ${ }^{67}$

Three main reasons underlie Siva's argument against the notion that gnosis alone can liberate. Firstly the nature of gnosis can be known at first but there is no accomplishment (sädhana) when gnosis alone arises, ${ }^{68}$ because the individual

${ }^{64}$ Dattātreyayogaśāstra 101-103ab (ete vighnā mahāsiddher na ramet teșu buddhimān| na darśayec ca kasmai cit svasāmarthyam hi sarvadā || kadā cid darśayet prītyā bhaktiyuktāya vā punaḥ | yathā mūrkho yathā müḍo yathā badhira eva vā || tathā varteta lokeșu svasāmarthyasya guptaye).

${ }^{65}$ The additional verses are 1-3ab, 65-6, 92, 94, 99-125, 148cd-149ab, 150ac, and 187 of the Gorakhnath Mandir Edition. Many of these verses are found in the Gorakșáataka, the Dattatreyayogaśāstra, and the Hațhapradīpikā. Two of them are unique to this recension of the Yogabija and the Hathapradipikā, so it remains a possibility that the former predates the latter. However, it also seems more likely that these extra verses were borrowed by Svātmārāma from a different work, which is currently unknown.

${ }^{66}$ These manuscripts are: Yogabija, Ms No. SB29917 (P.S. 49941, Ā. 8772), Saraswati Bhawan Library, Varanasi and Yogabija, Ms No. 72341, Adyar Library and Research Centre, Chennai. The former is in a Nepalese type of Devanagari and the latter is in Telugu script.

67 Yogabīja 18 (ajñānād eva saṃsāro jñānād eva vimucyate | yogenātra tu kiṃ kāryam me prasannagirā vada || yogenätra ] 29917: yogenaiva 72341).

${ }^{68}$ Yogabija 19 (satyam etat tvayoktam te kathayāmi sureśvari|jñānasvarūpam evādau jñeyam jñāne na sādhanam). 
(jīva) cannot be freed from faults $($ doșa $)$ by gnosis (19-21) ${ }^{69}$ in spite of knowing the aspected and aspectless nature of the self, the gnostic living in the world continues to be influenced by past impressions ( vāsanā) and cannot be liberated without yoga (22-29). Finally, gnostics whose bodies have not been cooked by the fire of yoga are subject to suffering, disease, and death (30-41), and only yogins conquer the body and death (42-54). In explaining the last reason, liberation-inlife is raised for the first time in the text as follows:

O moon-faced Goddess, you ask what death is for the [yogin]. He does not die again because of the power of yoga. He has already died. [Therefore,] how could death arise for one who has died? Where there is death for all [mortals], there he lives happily. However, where the deluded live, there he is always dead. There is nothing he ought to do and he is not stained by what he has done. He is always liberated-in-life, always resides in himself and free from all faults. [All] others, [namely] ascetics and gnostics, are always conquered by the body. How are they equal to yogins? They are lumps of flesh with defective bodies. ${ }^{70}$

In the Yogabija, the liberated yogin has the freedom to know everything and act at will, because of the attainment of siddhis:

[The yogin] becomes omniscient, can change shape at will and move as quickly as the wind. He plays in the three worlds and all the siddhis arise [for him]. A great yogin, he undoubtedly becomes a god, the creator of all, autonomous, may take all forms [at once], and is liberated-in-life. ${ }^{71}$

In keeping with the view that the yogin does not die, bodiless liberation (videha$m u k t i)$ is rejected explicitly. In fact, the author explains that the gross elements of the body are burnt up by the fire of yoga, which makes the body like ether ( $\bar{a} k \bar{a} s ́ a)$

${ }^{69}$ Yogabijja 21 (asau doșair vimuktah kim kāmakrodhabhayādibhih | sarvadoșair vṛto jīvo jñāne tu mucyate katham || vimuktah kim ] 72341 : vinirmuktah 29917. jñāne tu mucyate katham ] conj.: jñāne tan mucyate katham 72341 : jñäne to mucyate katham 29917).

${ }^{70}$ Yogabija 51-4 (maranam tasya kim devi prcchasinndusamānane| nāsau maranam äpnoti punar yogabalena tu || puraiva mṛta evāsau mṛtasya maraṇam kutah | maranam yatra sarveșām tatra jīvaty asau sukhī || yatra jīvanti mū ate ||58|| jīvanmuktah sadā svasthah sarvadoșavivarjitah || viraktā jñāninaś cānye dehena vijitāh sad̄̄ | te katham yogibhis tulyā māmsapiṇ̂̄ạh kudehinah || punar yogabalena ] 29917: yena yogabhavena 72341. atra jìvaty asau sukhī ] 29917 : tatrāsau jīvate sukhi 72341. müdhās ] 29917 : mukhās 72341. tu ] 29917 : te 72341. mriyate sad̄̄ ] Ed.: mriyate sadau 29917: mryate sadā 72341. tu na ] 29917 : na tu 72341. krtena na ] 72341 : krtenaiva 29917. vilipyate ] 29917 : vilavyate 72341. svasthah ] 29917 : -svacchaḥ 72341. -pindāh kudehinah ] 29917 : -pīdā hi dehinah 72341).

71 Yogabija 125, 127 (sarvajño 'sau bhavet kāmarūpah pavanavegavān | krīdate trișu lokeșu jāyante siddhayo 'khilāh $\|. .$.$\| îśvarah sarvakartā ca svatantro viśvarūpavān | jīvanmukto mahāyogī jāyate$ nätra samśayah). Manuscript 72341 is incomplete and ends at verse 123, so the readings for these verses and those below are based on manuscript 29917. 
and it cannot be seen, even by the gods. ${ }^{72}$ Moreover, an ageless and immortal body is a salient characteristic of the liberated yogin:

One should view a man without siddhis as bound. For, one whose body is ageless and immortal, he alone is liberated-in-life. Dogs, cocks, insects and the like obtain only death. Are they liberated with the fall of the body, O goddess? If the breath does not go out, how can the body die? However, liberation which is caused by the death of the body is not considered to be liberation [by me]. ${ }^{73}$

The Yogabija is the only early Hatha- and Rājayoga text that includes discourse on the philosophical questions underlying the soteriology of these types of yoga. Devîs probing questions appear to encapsulate some of the objections to yoga that would have been raised by gnostics who believed that liberation could be achieved by gnosis alone. The nature of its discourse suggests that the text was composed at a time when Hatha- and Rajjayoga had become prominent enough to attract scrutiny from other traditions, in particular Advaitavedānta and those that embraced the Mokṣopāya and the Yogavāsișța.

\subsection{The Khecarividya}

The Khecarividyā is not among the earliest works in this corpus, because it was composed after the Vivekamārtanda. ${ }^{74}$ This Saiva work calls itself a Tantra and focuses on the practice of khecarimudrā, which is included among the ten mudrās of most works on Hathayoga. ${ }^{75}$ Although the Khecarividya contains a detailed account of the physical practice of khecarimudrā, much of the text is devoted to explaining the metaphysics underlying the practice, which includes comprehensive descriptions of the various digits ( kalā) at important places in the yogic body, the drinking of nectar (amrta), and the raising of kundalini. The detail of these metaphysics, which is the basis of visualization practices, as well as other related topics, such as the worship of the text, the khecari mantra, yogic suicide, cheating death, and the worship of Siva, are redolent of the subject matter of earlier Tantras. Much of this material was omitted by texts that teach Hatha- and

\footnotetext{
72 Yogabīja 46-7ab (mahābhūtāni tattvāni saṃhṛtāni krameṇa ca | saptadhātumayam dehạ̣ dagdhạ̣ yogāgninā śanaih || devatābhir na laksyeta yogadeham mảābalam | saṃhṛ̂̄ni kramena ca ] 29917 : krameṇa saṃhrtāni ca 72341. devataiś ca ] 29917: devatābhir 72341. lakṣyeta ] 29917 : lakṣita 72341).

${ }^{73}$ Yogabija 139-40 (siddhibhị parihīnam tu naram baddham tu lakṣayet | ajarāmarapindo yo jīvanmuktah sa eva hi || śvānakukkuțakițādyā mṛtim samprāpnuvanti vai | teșām kị̣ piṇdapātena

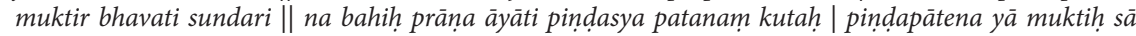
muktis na tu ganyate).

${ }^{74}$ Khecarìvidyā $(1.14 \mathrm{~cd})$ mentions the Vivekamārtanda.

${ }^{75}$ For example, Dattātreyayogaśāstra 137, Śivasaṃhitā 4.51-9, Hațapradīpikā 3.32-54, etc.
} 
Rājayoga and its inclusion in the Khecarividyā suggests that, like the Amrtasiddhi, this Tantra was composed in an esoteric milieu.

The Khecarividyā mentions liberation-in-life twice. In both instances (2.7 and 2.14), the yogin becomes a Siva, liberated-in-life by drinking the supreme nectar (parāmṛta) at the aperture of Brahmā. The drinking of nectar, which results from the practice of khecarimudrā, brings about a large number of supernatural effects (siddhi). This indicates that the attainment of siddhis was of primary importance to the author. Furthermore, the notion of samädhi (unmani and laya) is mentioned several times, but only in passing. ${ }^{76}$ Within the broader context of the visualization practices and the emphasis on drinking nectar, samädhi is presented more like a supernatural effect (siddhi) than an auxiliary in a system of yoga. The absence of descriptions of the liberated yogin in a hypometabolic state further suggests that samādhi is incidental to the main transformative processes of raising kuṇdalinī and drinking nectar. Like earlier Saivasiddhānta traditions, the Khecarividya (3.48-54ab) also teaches yogic suicide so that the yogin may cast off his body and become like Siva. Therefore, the siddhis and the deification, as it were, of the liberated yogin characterize the soteriological aim of this work.

\subsection{The Sivasamnitā}

The Śivasamhitā twice calls itself a Tantra $(4.7,4.25)$. Its teachings are influenced by the Śrīvidyā of South India (Mallinson 2007b: ix-xiv), a tantric tradition which was reformed by Smārta Brahmins. It flourished in the major temples of Shringeri and Kanchipuram (Golovkova 2012: 817).

The first two chapters of the Sivasam hitā teach Śaiva doctrine (jñāna), which espouses the gnostic views of attaining samādhi by simply seeing the Self (1.63-4) and renouncing Vedic ritual in favour of knowledge (1.20-32). Chapters three and four teach the techniques of Hathayoga, without naming it as such and without referring to Rājayoga. Samādhi is mentioned in the third chapter. As stated in other Hatha- and Rājayoga texts, ${ }^{77}$ when the stage of perfection (nispatti) is attained, samādhi arises at will (3.76-7). Apart from mentioning that this results in the breath dissolving into the power of gnosis (jñānaśakti) (3.78), nothing more is said of samädhi in this chapter.

The last chapter, which may have been composed originally as a separate text (Birch 2018b: 107 n. 13), teaches a system of four yogas, Mantra-, Laya-, Hatha-, and Rajjayoga, the last of which is said to be free from the state of duality (5.12). This fourfold system appears to provide only a superficial framework for the fifth chapter, because it is barely discernible in the chapter's overall structure. Indeed,

${ }^{76}$ Khecarīividyā 2.67, 113 and 3.24, 52.

77 For example, Dattātreyayogaśāstra 160-2, Amaraughaprabodha 36-44, Hațapradīpikā 4.70-80, etc. 
this chapter mainly consists of instructions on various visualization techniques (5.29-5.207), most of which are based on the yogic body of nādìs, cakras, kundalinī, and so on. In a concluding verse (5.208), these meditations (dhyāna) are said to be Rajjayoga, at which point rājädhirājayoga, 'the yoga that is the supreme king of all Rājayogas', is introduced. Through vedāntic reasoning (vedāntayukti), the yogin frees himself of mental activity and attains the ultimate, pure knowledge (ekam amalam jñāna) (5.210-21), which results in the following:

While living in an unchanging body the yogin, who now dies frequently to the pleasures of the sense objects, certainly lives. ${ }^{78}$

The emphasis on knowledge, visualization practices, and immortality in the Śivasam hitä's fifth chapter appears to have been intended for householders, who might well have preferred its gnostic and siddhi-orientated practice to the ascetic stillness of Rajjayoga in other works consulted for this study. Liberation-in-life is not mentioned in the first four chapters of the Sivasamhita,${ }^{79}$ but it is indicated as the goal of rājādhirājayoga at the end of the fifth chapter:

Satisfied with acquiring things by chance and having abandoned his attachments within, the householder is liberated $\dagger$ from all bonds $\uparrow$ by the methods of yoga. ${ }^{80}$ By just repeating the mantras of the gods, ${ }^{81}$ householders can succeed. ${ }^{82}$ Therefore, of those engaged in the practice of yoga, the householder [should] persevere. Having remained in the house, full of sons, a wife and so on, while

${ }^{78}$ Śivasamhitā 5.223 (sthite dehe jīvati yo adhunā mriyate bhrúam | indriyārthopabhogeșu sa jīvati na samśayah || 5.223 || 223a jīvati ] Ed.: jīvatī V: jivati XI. 223a-b yo adhunā ] mss. II, III, XI-XIV: yoh adhunā V: yo anśunā IV: yodhunā VI, VIII: ca yogam na Ed. 223b mriyate ] mss. II-VI, XI-XIV: mrīyate VII: agriyate VIII: śriyate Ed. 223c indriyārthopabhogesu ] Ed.: indriyārthāpabhogeșu III: indriyārthāya bhogeșu IV, V, VII, VIII, XII-XIV. 223d sa jīvati ] Ed. sa jīvanti III: sañjīvati IV. The first $p \bar{a} d a$ is a rare form of the bha-vipula. The reading yo adhunā (supported by nearly all the manuscripts) is unconventional but appears to be a case of frozen sandhi which sometimes occurs in Āgamic Sanskrit (Goodall 2015: 133). These variant readings have been taken from the apparatus in Siva Samhitā: A Critical Edition (2009). The numerals I, XV, and XVI are past editions. The oldest Ms is XII, dated samvat 1805 (1749 CE).

79 As far as I am aware, all editions (the exception being Mallinson 2007b) have in their third chapter the hemistich jivanmuktasya śantasya bhaved dhirasya yoginah, but it is absent in nearly all the manuscripts (i.e. II-IV, VII-XII) reported in the critical edition of the Śivasaṃhitä (2009: 131).

${ }^{80}$ Most manuscripts have sakaläśeșo muktah or something similar, but this does not make sense. In the conjecture sakaläśleșamuktah, the word äśleșa, which literally means a 'connection' or 'embrace', has been understood as another term for mundane attachments.

${ }^{81}$ The practice of mantras (mantrasädhana) is a significant part of the Śivasamnhitä’s fifth chapter (5.232-5.252).

${ }_{82}$ The occurrence of iśsvarānām is unexpected here, but it is supported by the manuscripts (see footnote 83). I have understood it as qualifying japena. An alternative interpretation would be to understand iśvara in its more mundane sense of a 'lord' or 'king', and read it along with gṛasthānām as qualifying siddhih, in spite of the absence of a conjunctive particle such as $c a$ (i.e. 'householders and kings have success by repeating a mantra'). The problem with this reading is that iśvara is used elsewhere in the text to mean 'god', in particular Śiva, who is the main interlocutor in the dialogue. 
abandoning attachments within and seeing a sign of success on the path of yoga, the householder may truly amuse [himself], having accomplished my teachings. ${ }^{83}$

This conclusion reflects the Sivasamhitä's strong emphasis on siddhis. The final statement that the liberated householder may amuse himself is redolent of Śaiva yogins of earlier traditions, who sought siddhis merely for their own entertainment $(k r \bar{i} d \bar{a})$. These yogins appear to have been inspired by a story of Siva's descent into the world for his own enjoyment (krī dāvatāra) (Vasudeva 2011: 288).

\section{General Remarks on the Early History of Rājayoga}

From a purely grammatical viewpoint, the term räjayoga can be understood in various ways. However, the survey of early Hațh- and Rājayoga texts used by Svātmārāma for his Hațhapradīpikā indicates that it was used as a karmadhāraya compound, ${ }^{84}$ in the sense of the yoga that is the king of all yogas. The evidence for this is threefold. Firstly, the context is usually the four yogas, and Rajayoga is presented as the best (uttama) of the other three. ${ }^{85}$ Secondly, the Amanaska, which is probably the earliest of these works, defines räjayoga as the king of all yogas. ${ }^{86}$ Thirdly, the notion of 'king' or 'supreme' yoga is strongly implied by the fact that räjayoga is the goal of the other yogas and at the top of a hierarchy of other yogas. ${ }^{87}$ Three texts of the corpus, namely the Amaraughaprabodha, the

${ }^{83}$ Śivasaṃitā 5.258-60 (yadrcchālābhasantușțh santyaktāntarasañgakah | grhasthah $\dagger$ †sakalāśleșamuktaḥ syād yogasādhanaih ||5.258|| gṛhasthānām bhavet siddhir ìśvarānāạ japena vai $\mid$ yogakriyābhiyuktānām tasmāt samyatate gṛhī ||5.259|| gehe sthitvā putradārādipūrne sà̃gam tyaktvā cāntare yogamārge | siddheś cihnam vīkșya paścād gṛhasthah krīdet sa vai me matam sādhayitvā \|5.260|| 258b santyaktāntarasañgakah ] Ed.: santyaktāntarasañjñakah IV, VII, XII: sañgam nyaktvāntarangakaḥ II: santyaktāntah sañjnakah III: santyaktvātarasañjñakah VI: santyaktvāntarasañjñakah IX, X. 258c grahasthah sakalāśleșa- ] conj. Dominic Goodall: grahasthah sakalāśeșo II, V, VIII, XII: gṛhasthā sakalāśeșo III, IV: gṛhasthah sakalāśeșo VI, VII, IX, X, XIV: gṛhasthah sakalāseșo XIII: gṛhasthaś vāpy anāsaktah XVI: gṛhasthaś cāpy anāsaktah Ed. 258d muktah. syād ] II, III, V-X, XII XIII: muktā syāt IV: sa mukto Ed. yogasādhanaih ] Ed. yogasādhanāt I, XV, XVI: yogasādhane V. 259b ìśvarāṇām japena ] I, XV, XVI: íśvarāṇām janena III-X, XIII, XIV: ìśvarāṇāṃ janeta XII: iśvarārādhanena Ed. 259c kriyābhiyuktānām ] Ed.: kriyābhih yuktānām XII. 269d tasmät samyatate ] Ed.: tasmāt sammadyate II: tasmāt saṃsantata XIII. 260a gehe ] Ed. grahe III: gṛhe IV: he XII: gahe XIV. sthitvā ] corr.: sthitā Ed. -pūrṇe ] Ed.: pūrṇah I, XV, XVI: -pūrnaih II, XII: pūrṇo IV. 260b cāntare ] Ed.: cāntaram VIII. yogamārge ] Ed. yogamärgam II, III, VII. 260c siddheś cihnam ] Ed. siddheś cihna II: siddhe cihnam XV, XVI. vîkṣya ] Ed. vìkṣa IV. 260d. grhasthah ] Ed. gṛhastha VII). I wish to thank both Diwakar Acharya and Dominic Goodall for their comments on the above passages in the Sivasamhitā.

${ }^{84}$ A type of compound in which both nouns are in an appositional relationship.

${ }^{85}$ For example, Dattātreyayogaśāstra 9cd-10ab: 'Mantra-, Laya and Hațayoga [are the first three yogas]. Rajjayoga is the fourth and it is the best of yogas' (mantrayogo layaś caiva hathayogas tathaiva ca || rājayogaś caturthah syād yogānām uttamas tu saḥ).

${ }_{86}$ Amanaska 3cd (räjatvāt sarvayogānām rājayoga iti smṛtah).

${ }^{87}$ For example, Amaraughaprabodha 74cd (layamantrahathāh proktāh rājayogāya kevalam) and Yogabija 143cd (mantro hațo layo rājā yoge ntarbhümikāh kramāt). This is also true for the Amanaska, which teaches only Rājayoga. The beginning of its second chapter mentions a preliminary yoga (pūrvayoga), which is not described. 
Dattātreyayogaśāstra, and the Yogabīja, establish a fourfold hierarchy in which Rajjayoga is the principal one, and the goal of the subordinate yogas. This is also true for the twofold systems of the Amanaska, the Yogatārāvali, and the Hathapradīpikā. The Śivasam hitā is an interesting exception insofar as it includes the standard fourfold hierarchy and makes Rājayoga subordinate to rājādhirājayoga. The attempt to supplant Rājayoga with a higher Rājayoga (namely adhirājayoga) suggests that competitive extension was at play among traditions, which vied with one another to teach the 'best yoga'. This might explain the ongoing use of the term räjayoga with this meaning, which can be construed in many yoga texts composed after the fifteenth century (Birch 2014: 411-14).

As the above survey of texts demonstrates, the notion of Rajjayoga as 'kingyoga' also derives from its soteriological status, for it is the only type of yoga that can bring about liberation. In this context, the meaning of rājayoga becomes synonymous with samādhi. The second definition of rājayoga in the Amanaska identifies it as the yoga that enables the yogin to attain the supreme self (paramātman), which is the king (rājan) of all beings, as stated in the Brihadāranyakopanișat (Birch 2014: 406-7). A subsequent verse in the same text (2.32) indicates clearly that räjayoga denotes the state in which one's mind is absent (vigatanijamanoräjayoga). Therefore, one might infer that the second definition in the Amanaska posits räjayoga, in the sense of samädhi, as the means to liberation. Other works in this early corpus define rājayoga as 'free of mental activity, ${ }^{88}$ a non-dual state, ${ }^{89}$ oneness of mind, ${ }^{90}$ and beyond the exertion of concentration and meditation. ${ }^{91}$ All of these texts either state or imply that it arises when the activity of breath and mind ceases. ${ }^{92}$ Therefore, rājayoga can be understood as both the goal of other yogas and the means to liberation.

The earliest use of the term rājayoga to designate the 'best yoga' may have originated in the north-west of India. This is suggested firstly by the fact that Hemacandra, who lived in Gujarat in the twelfth century, borrowed many verses on samādhi from the Amanaska, which calls its yoga rājayoga. Hemacandra did not incorporate the term rājayoga into his Yogaśāstra, perhaps because his work is structured according to auxiliaries (ánga), rather than a hierarchy of different yogas. Nonetheless, he borrowed a sufficient number of verses from the Amanaska to indicate that this type of yoga was prominent enough in Gujarat to be known by a Jain scholar in the court of king Siddharāja Jayasimpha (1093-1142 CE). Secondly, Kashmiri exegetes of the tenth century onwards describe the main

${ }^{88}$ Amaraughaprabodha 4 (translated in section 1).

${ }^{89}$ Amaraughaprabodha 3cd (caturtho rājayogaśca dvidhābhavavivarjitah); Yogatārāvalī 16, which states that there is no subject-object experience (see Birch 2015: 4); Śivasaṃhitā 5.12.

${ }_{90}$ Amaraughaprabodha 53ab (ekībhütam tadā cittam rājayogābhidhānakam); Śivasamhitā 5.154ab.

91 Yogatārāvalī 14cd (na dhāraṇādhyānapariśramo vā samedhamāne sati rājayoge).

92 Evidence for this is given in section 1. The Yogabija implies this because Rajjayoga is the culmination of a sequence, where it follows Hathayoga, in which the breath is held in the central channel, and Layayoga, the dissolution of the mind. 
technique of the Amanaska (i.e. śâmbhavì mudrā) in almost identical words and call it bhairavamudrā (Birch 2014: 408 n. 30), further suggesting that this type of yoga arose in the north-west of India.

The combining of Rajjayoga with Hathayoga into a complementary system, which is not evident in the Amanaska, appears to have occurred a century or so later in the Amaraughaprabodha and the Dattātreyayogaśāstra. The former refers to Siddhabuddha and borrowed material from the Amrtasiddhi, which suggests the text was composed in Kadri, Mangalore (Mallinson 2019: 23-4), probably in the twelfth century (Birch 2019: 23-4). The latter was known in Rajasthan by the fourteenth century, because some of its verses were reproduced in the Śārngadharapaddhati. ${ }^{93}$ The combining of Hatha- and Rājayoga dissolved tensions between effortful and effortless methods of yoga for achieving samädhi, which were articulated in the Amanaska (Birch 2011: 542-7). In particular, the fourfold system of yoga validated both effortful and effortless methods by allocating each yoga to different types of student, and the twofold system of the Yogatārāvalī integrated Hatha- and Rājayoga as the method and goal respectively.

Although the term rājayoga may be construed as 'yoga for kings', it is difficult to see how this type of yoga was ever intended for kings in the literal sense. The siddhi-orientated liberation of some of the early Rajjayoga works might have appealed to kings, but the requisite practice of a stonelike state of samädhi seems impractical for people with state or institutional responsibilities. Furthermore, the texts advocating the Hațha-Rāja method do not mention kings and do not contain explicit metaphorical play on the word 'king. Even in the context of liberation, the yogin is portrayed as a god living in the world, rather than a king. ${ }^{94}$

\section{Rājayoga and Liberation-in-Life}

From the above survey of Sanskrit yoga texts, the following three general observations on Rajjayoga and its associated conception of liberation can be made. Firstly, each text teaches a system of yoga which has liberation as its main goal. Secondly, Rajjayoga, which is synonymous with samädhi, is the culmination of practice and a necessary cause for liberation. ${ }^{95}$ Thirdly, liberation can be achieved within one lifetime and the yogin continues to live after liberation is accomplished. Although these texts promise liberation-in-life (jivvanmukti) by means of samädhi, two differing conceptions of the liberated yogin emerged and were integrated to varying degrees.

93 On the provenance of the Śärngadharapaddhati, see Sternbach 1974: 17.

${ }^{94}$ In fact, I am aware of only two vedāntic works which define rājayoga as 'yoga for kings' and both probably date to the eighteenth century (Birch 2014: 412). The Vivekadarpana strongly implies it (see below).

${ }_{95}$ As noted in section 1, the Khecarividya is an exception in this case. 
On the one hand, liberation-in-life is identified with samädhi, insofar as the yogin in samädhi is liberated and the liberated yogin must continue to practise it. The texts that most clearly represent this view are the Vivekamärtanda, the Candrāvalokana, the Yogatārāvalī, the Amanaska, and the Gorakșaśataka. These works tend to emphasize the transcendent and blissful experience of samädhi and, although siddhis may arise from the practice, the role of siddhis in defining liberation is less significant. In this respect, the Vasișthasamhitā and the Yogayajjnavalkya are similar to these texts and, by identifying yoga with the daily rites (nityakarma) enjoined by the Vedas, the logical outcome of both works is the ongoing need to practise yoga, even for one who is liberated-in-life.

On the other hand, liberation-in-life is described as the outcome of a transformative process that takes place in samädhi. In other words, the liberated yogin emerges from samādhi as an all-powerful god who can know and do anything in the world. The texts most clearly supporting this view are the Sivasamhita, the Khecarividyā, the Yogabīja, the Dattātreyayogaśāstra, and the Amaraughaprabodha. The liberated yogin is said to attain all the siddhis which, in the Dattātreyayogaśāstra, includes the power to be inactive. The Amrtasiddhi appears to sit halfway between these texts and those that emphasize transcendence, because its liberation is very much orientated towards the attainment of siddhis, yet the liberated yogin remains in samädhi, secluded from the world.

Although the paradigm of transcendence and power can be used to identify the differing roles of siddhis and the practice of yoga after liberation in these texts, it does not provide a reason for why an author emphasized one rather than the other. One might speculate that divergent views on the rigidity of karma were at play. Although all of the texts in question accept that the practice of yoga can destroy a yogin's past karma, some advocate the need for ongoing practice after liberation, whereas others assume that the liberated yogin can act in the world and remain untouched by karma. The latter view relies on theistic notions of liberation that derive from earlier tantric traditions, in particular the Kaulism associated with Matsyendranatha, who was also one of the supposed founders of Hathayoga. ${ }^{96}$ For example, the Kaulajñannanirnaya, which is a text attributed to Matsyendranātha and may date to the tenth century, ${ }^{97}$ directly connects liberation to the attainment of the no-mind state, ${ }^{98}$ and describes the king of yogins (yogirāt) as a godlike figure who is active in the world after liberation:

\footnotetext{
${ }^{96}$ For example, Matsyendranātha is close to the beginning of a lineage of gurus in Haṭapradīpikā 1.4ab.

97 The Kaulajñannanirnaya certainly predates the mid-eleventh century, which is the date of its earliest manuscript. For details on this, see Hatley 2007: 157-8 n. 77. Shaman Hatley has informed me that he suspects that the Kaulajñannanirnaya belongs to the tenth century and he is hopeful that his ongoing research on this text will confirm this (p.c. 24.1.2017).

${ }_{98}$ For example, Kaulajñānanirnaya 13.5: '[Now,] there is no mind, mental activity [nor] support, no meditation object [nor] concentration, $\mathrm{O}$ goddess. He whose mind has become no-mind, has liberation †in this world †' (na manaś cittam ālambam na dhyeyam dhäraṇam priye | unmanan tu mano
} 
When one knows the self by the self, the self can take any form at will. The self is the supreme deity. He by whom this is known is the king of yogins. He is said to be Siva. He is clearly liberated and may liberate another. O goddess, he is always very pure, like a lotus in the mud. Having adopted a mortal body, he sports in the world as a Śiva. ${ }^{99}$

In describing the liberated yogin as an equal to Siva (śivatulya) and one who can move and behave at will (svacchandagaticeștita) (5.24cd), the Kaulajñānanirnaya provides a doctrinal antecedent to the conception of liberation seen in texts such as the Amaraughaprabodha, the Dattātreyayogaśāstra, the Yogabija, and the Sivasamhitā. In fact, the idea that the yogin can live as long as he wants and roam the world at will can be found in other Kaula scriptures. ${ }^{100}$

There is also an example of a more recent Śaiva work which grafted a Kaula view of liberation onto the practice of the death-like state of samädhi, which is also described in similar terms in the Hathapradipika (see below). The ninth chapter of the Kulärnavatantra, a Kaula text of the Upper Tradition ( $\bar{u}$ rdhvāmnàya) that probably postdates the thirteenth century, ${ }^{101}$ borrows verses from both the

yasya tasya mokṣo †bhavaty iha† ||5|| 5a manaś ] A48/13: manaṃ Ed. 5a ālambam ] A48/13 : ālabdham Ed. 5b dhyeyam ] emend. Hatley: dheyam A48/13 : peya Ed. 5d bhavaty iha ] conj. Hatley: bhavantiha A48/13 : bhavantiha Ed. I have cruxed the conjecture bhavaty iha simply to indicate that this crucial reading is not clear in the old Nepalese manuscript or the edition, although Shaman Hatley's conjecture is a good one based on the evidence. Liberation at death (moksah [...] pindapäte) is mentioned in the final verse of this chapter. However, there the context is the practice of sequentially installing seed syllables (nyāsakrama) in the body.

${ }^{99}$ Kaulajūānanirnaya 17.36-8 (ātmānam àtmanā jñātvā ātmā vai kāmarūpinah |àtmanaś ca paro devo yena jūātam sa yogirāt ||36|| sa śivah procyate sākṣāt sa mukto mocayet param| suviśuddhah sadā devi pankkastham iva pan்kajam ||37|| mānusyam piṇdam āsṛtya sa śivah krīdate bhuvi | itthambhūtam parātmānam yena jũätam subhāmini|). I wish to thank Shaman Hatley for pointing out this passage to me and for sharing his provisional edition of these verses. The compound kämarupinah has been understood as an aśia form of the nominative singular, and $36 \mathrm{c}$ is a conjecture by Hatley (the codex has àtmanaś cāparo devi). Also, one should read àsṛtya as an orthographic variant of àśritya (Hatley p.c. 1.2.2017).

${ }^{100}$ For example, the Kulasāra f.25v (svecchāyur bhavate yogī tadabhyāsān na saṃśayah) and (na mṛtyor bhayam etena jāyate 'bhyāsayogatah | svecchāyur jāyate yogī svadehenìśvaro bhavet) and the Kuladīpikā (IFP transcript T1046a) p. 15 (uttișţhan medinīn tyaktvā divyadehah prajāyate| paryatet svecchayā lokāmnś chidrām paśyati medinīm \|| chidrāṃ ] emend. Vasudeva (p.c. 25.1.2017): citrāṃ Codex) and p. 72 (bhramate svecchayā lokāmś chidrām paśyati medinīm |bhramate ] emend. Vasudeva (p.c. 25.1.2017): bhrūmate Codex. lokāmś chidrām ] emend. Vasudeva (p.c. 25.1.2017): lokācchidrān Codex. paśyati ] emend.: paśyanti Codex). I wish to thank Somdev Vasudeva (p.c. 25.1.2017) for these references, as well as for pointing out to me that the idea that a yogin can live as long as he pleases is also found in the Śaivasiddhānta (e.g. Mrgendratantra's Yogapāda 46: jitapranayano dhatte svecchayā deham ātmanah | Nārāyaṇakaṇtha comments: jitā praṇayanākhyā prānavrụttir yena sa evamvidho yogì yāvadruci svecchayā svadehaṃ dhārayati [...]). Also, see Matañgapārameśvaratantra Yogapāda 7.34. Thanks to Lubomír Ondračka for this final reference.

${ }^{101}$ For a discussion on the Kulärnavatantra, see Sanderson 2014: 78, wherein Alexis Sanderson states that it postdates the twelfth century. The Kulärnavatantra shares a verse with the Vivekamärtanda on the Hațhayogic Mudrās; Kulārnavatantra 13.85 (mahāmudrām nabhomudrām udḍ̄yānam jalandharam | mūlabandhañ ca yo vetti sa guruh paramo matah) Vivekamārtanda 40 (mahāmudrām nabhomudrām uddìyānam jalandharam | mūlabandham ca yo vetti sa yogī muktibhājanam). Also, there are other parallels between the Kulärnavatantra and the Vivekamärtanda noted in footnote 102. 
Amanaska and the Vivekamārtanda. ${ }^{102}$ The Kulärnavatantra uses the same metaphors and language as the yoga texts in question to describe samādhi. For example, the following verse equates the death-like stillness of this samädhi to liberation-in-life:

[The yogin] whose sensory organs are inactive; whose mind and breath have dissolved into himself and who clearly remains [still] like a corpse, is said to be liberated-in-life. ${ }^{103}$

The interesting difference between the Vivekamärtanda and the Kulärnavatantra's chapter on yoga is that the Kulärnava's liberated kulayogin emerges from his death-like samädhi to interact with people, concealing his identity. For example:

Although liberated, the lord of the Kula plays like a child and behaves like an idiot. The wise kulayogin speaks like a madman, O goddess. The yogin lives in such a way that people laugh, shun and abuse him. They move far away when they see him. Wearing various outfits, the yogin wanders the world; sometimes [looking] cultured, sometimes wretched and sometimes like [the supernatural beings called] bhūtas or piśācas. ${ }^{104}$

Such details of how the liberated yogin might behave are absent in the Hatha- and Rajjayoga works examined in this chapter. Their authors seem to have been unwilling to present the worldly adventures of the liberated yogin as fully as they were developed in Kaula traditions. Nonetheless, an early Marathi work (twelfth to thirteenth century) called the Vivekadarpana is something of an exception here. ${ }^{105}$ In its chapter on Rājayoga, a set of four yogas, namely Mantra-, Laya-, Hatha-, and Rajjayoga, are defined. Redolent of the Amanaska's point of view, the

Since the former does not teach these mudrās but the latter does, it is likely that the Kulärnavatantra is the borrower. The terminus ad quem of the Vivekamärtanda is the Khecarividyā (Mallinson 2007a: 4) or the Śarngadharapaddhati (Bouy 1994: 25), the latter of which can be dated to $1363 \mathrm{CE}$. Therefore, if we assign the Vivekamärtanda to the twelfth or thirteenth century, the Kulärnavatantra, in its published form, probably postdates the thirteenth or fourteenth century.

${ }^{102}$ Cf. Kulārnavatantra 9.13-15 (na śrṇoti na cāghrāti na sprśáti na paśyati | na jānāti sukham duḥkham na sànkalpayate manah ||13|| na cāpi kiñ cij jānāti na ca budhyati kāṣthavat | evam śive vilìnātmā samādhistha ihocyate ||14|| yathā jale jalam kșiptam kșīre kșīram ghṛte ghṛtam | aviśeșo bhavet tadvaj jīvātmaparamätmanoh) with Vivekamärtanda 162-72 (cited and translated above). Also, Kulärnavatantra 9.10 and $9.11=$ Amanaska $2.54 \mathrm{~cd}-2.55 \mathrm{ab}$ and 2.59. Most of the Kulärnava's ninth chapter is quoted with attribution in the seventeenth-century Yuktabhavadeva (1.55-1.106), as a passage concerning the king of yogas (yogarājam adhikrtya kulārnave).

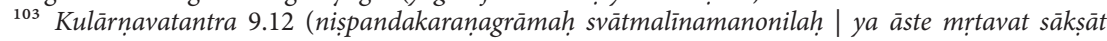
jīvanmuktah sa ucyate).

${ }^{104}$ Kulärnavatantra 9.72-4 (mukto 'pi bālavat krīdet kuleśo jadavac caret | vaded unmattavad vidvān kulayogì maheśvari ||72|| yathā hasati loko 'yam jugupsati ca kutsati | vilokya dūrato yāti tathā yogī pravartate ||73|| kva cic chiștah kva cid bhraștaḥ kva cid bhūtapiśācavat | nānāveșadharo yogì vicarej jagatītale \|74|| 74c veșa ] corr.: veśa Ed.).

105 Additional verses on the Rajayogin in the long recension of the Amaraughaprabodha (71-3) are also relevant here. For a translation, see Birch 2019: 10-11. 
first three are rejected as causes of suffering. However, the Vivekadarpana defines Rajayoga in more gnostic terms as 'stilling the fluctuations of the mind through one's own knowledge. ${ }^{106}$ The Rajayogin is then likened to a king who rules his body and senses and, like the Kularnavatantra, can live in the world as a naked, solitary ascetic or a libertine, so to speak. ${ }^{107}$

Finally, it should be noted that the acceptance of liberation-in-life in Hathaand Rajjayoga texts is not exceptional in the history of yoga and Indian religions. Indeed, the authors of these yoga texts would have been aware of the teachings on liberation-in-life in some earlier works on yoga, such as the Pātañjalayogaśästra ${ }^{108}$

106 Vivekadarpana 15.1: 'Knowing the fluctuations of the mind to be impermanent, they become still through one's own knowledge, that is Rājayoga' (citavṛtī anitya jānauni äpuleni jũānem nìścalā hoūni āsije to rājayauguh).

107 Vivekadarpana 15.3 (kavhane yekyem țāim nagnah dīgāmbaruh ānīkye țāim dīvyāmbarah

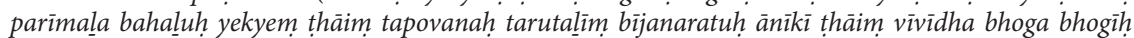
sahajaprāpta puramdharuh sarvatra pratībamdhuh bamdhanārahìtu houni àseh tyātem rājayaugī mhanijeh). To understand this passage, I have relied on the German translation of Reinelt 2000: 240-1 (An irgendeinem Ort [ist er] ein Nackter, einer, dessen Gewand die Himmelsrichtungen sind, an einem anderen Ort einer mit himmlischem Gewand [und mit] reichliche[n] Wohlgerüche[n]. An [irgend] einem Ort [ist] ein Wald für Askese, [dort ist er] am Fuß eines Baumes der Einsamkeit zugetan. An einem anderen Ort genießt er vielfältige Freuden, [die er] auf natürliche Weise erlangt [wie] Indra. [Auch wenn] überall behindert, lebt er ohne Bindung. Er wird ein glücklicher rājayogī genannt), which I have understood as, 'In some place he is a naked person, one whose garments are the cardinal directions, in another place he is someone with a heavenly garment [and with] abundant fragrance. In some place [like] a forest for asceticism, [there he is] at the foot of a tree devoted to solitude. In another place he enjoys manifold pleasures, [which he] attains naturally [like] Indra. [Even though] handicapped everywhere, he lives without bond. He is called a happy rājayogî. However, I suspect digāmbaruh means 'sky-clad' and not 'garments that are the cardinal directions'. I would like to thank Nils Jacob Liersch for his assistance with my translation of the German.

${ }_{08}$ Three sections of the Pätañjalayogaśāstra allude to liberation-in-life, although the term jīvanmukti is not used. The first occurs in the commentary (bhāsya) to sütra 1.16, in which the higher form of detachment (vairägya) is said to be identical to liberation (kaivalya). The yogin who attains it is obviously alive because he realizes 'what is to be attained has been attained, etc.' (Pätañjalayogaśästra 1.16: [...] evam manyate-präptam präpaniyam [...]). The second indication of liberation-in-life occurs in a passage on the sevenfold wisdom (prajña ) gained by the fourth type of yogin, who is described as one who has surpassed what ought to be done and whose sole goal is the dissolution of the mind. See a translation and discussion of Pātañjalayogaśästra 3.51 (caturtho yas tv atikrāntabhāvanìyas tasya cittapratisarga eko 'rthaḥ| saptavidhāsya prāntabhūmiprajñā) in Maas 2014: 17. This passage concludes with the following statement, 'When the Purușa experiences the sevenfold wisdom at its final stage (prāntabhūmi), it is called wise (kuśala). Also, when the [yogin's] mind returns to its primordial state, Purușa is both wise and liberated, because it is beyond the Gunas' (Pātañjalayogaśāstra 2.27: etām saptavidhām prāntabhūmiprajñām anupaśyan purușạ kuśala ity ākhyāyate | pratiprasave 'pi cittasya muktah kuśala ity eva bhavati gunātìtatvād iti). As the pronoun tasya in sütra 2.27 indicates, this sevenfold wisdom arises for the yogin who can discern Purușas fundamental isolation (pratyuditakhyatti). As Purușa in the above passage, such a yogin is described elsewhere as kuśala, a term which implies that he is free from transmigration (on the meaning of kuśala in the Pātañjalayogaśāstra, see Maas 2014: 15 and Wezler 2001: $301 \mathrm{n}$. 52. Both Maas and Wezler conclude that kuśala and mukta are 'equivalents'). The fact that liberation may arise either when the sevenfold wisdom is experienced or when the mind dissolves appears to reflect the two alternative explanations of liberation (kaivalya) in sütra 4.34: 'Liberation is the dissolution of the gunas which are [now] void of purpose for the Purușa, or it is the power of consciousness (i.e., the Puruṣa) established in its own form' (Pātañjalayogaśástra 4.34: purușārthaśūnyānām gunānām pratiprasavah kaivalyạ̣ svarūpapratisth $\bar{a} v \bar{a}$ citiśaktir iti). Note that $v \bar{a}$ in this sūtra is glossed as punah in the bhäsya. The third indication of liberation-in-life occurs in the bhäsya on sütra 4.30, which exclaims that the yogin's afflictions, such as ignorance, and accumulated karma end (kleśakarmanivrtti) when he has achieved the state of samädhi called 'the cloud that rains virtue' (dharmamegha). At this point, the wise yogin is freed (vimukta) while living: 'When the afflictions and accumulated karma have ceased, the wise [yogin] 
and the Yogavāsistha.$^{109}$ Furthermore, other traditions, such as Advaitavedānta ${ }^{110}$ and Rasaśāstra, ${ }^{111}$ which flourished in the same time period as early Hațha- and Rājayoga, envisage liberation-in-life in various ways.

\section{Rājayoga and Liberation in the Hathapradīpikā}

Having identified the shifting emphasis on transcendence and power in early Hatha- and Rājayoga works, it is now possible to understand how Svātmārāma resolved the differences in his Hathapradipikā. Although the title of his work suggests that it mainly concerns Hathayoga, Svātmārāma indicates clearly that Hathayoga is the means to Rajjayoga and that the yogin cannot succeed at one without the other. ${ }^{112}$ Moreover, the fourth and final chapter of the Hathapradipika is exclusively on Rājayoga.

The first three chapters of the Hathapradipika explain the principal techniques of Hathayoga, namely āsana, prānāyāma, and mudrā. There are passing references to liberation in the descriptions of some of these techniques, siddhäsana (1.37), padmāsana (1.51), uddìyānabandha (3.60), sahajoli (3.94), amaroli (3.103), and śakticālana $(3.105,107)$. Although one might infer that these techniques were considered salvific because of their efficacy in inducing samädhi, ${ }^{113}$ the verses on these techniques that mention liberation do not indicate whether it is siddhiorientated or otherwise. ${ }^{114}$

is liberated while he is still living' (Pātañjalayogaśāstra 4.30: kleśakarmanivṛttau jīvann eva vidvān vimukto bhavati). Therefore, as was the case in early Buddhism, Patañjali thought that liberation-inlife was possible. For the contrary view, which gives subsequent commentaries equal weight to the Pātañjalayogaśästra's bhāṣya, see T.S. Rukmani (1997). Note that Śankkara's commentary on the Pâtañjalayogaśástra does not seem to doubt that the yogin is alive when liberated. His commentary on sütra 1.25 (56.15) appears to assume that a perfected yogin (siddhayogin), who is free from the afflictions, is alive: 'İ́vara is free from flaws (kleśa), and so on; because he has an unobstructed knowledge; like an accomplished yogin' (trans. Harimoto 2014: 106).

109 See Slaje 2000a and 2000b. $\quad 110$ See Potter 1998 and Fort 1998.

111 The Yogabija's rejection of bodiless liberation in favour of liberation-in-life is somewhat similar to Bhairava's discussion of liberation-in-life in the Rasārnava: 'Liberation-in-life occurs when one whose body is ageless and immortal experiences their identity with Śiva, O great Goddess. It is difficult to obtain even for the gods. Liberation at death is a futile liberation. When the body dies, even an ass is freed. [...] Therefore, one should preserve the body with potions and elixirs' (Rasārnava 1.8-1.9, 1.11ab: ajarāmaradehasya śivatādātmyavedanam | jīvanmuktir mahādevi devānām api durlabhā ||8|| piṇ̦apāte ca yo mokșah sa ca mokșo nirarthakah |piṇde tu patite devi gardabho 'pi vimucyate || 9||$[\ldots]$ tasmät samrakșayet piṇdạ̣ rasaiś caiva rasāyanaih).

${ }_{112}$ The relationship between these yogas is stated explicitly at the beginning of the Hathapradipika (1.1-3) and elsewhere (e.g. 2.76; for a translation, see Birch 2011: 546 n. 137).

${ }_{113}$ For example, the connection between samädhi and liberation appears to be behind the claim that siddhāsana bestows liberation, because it supposedly induces samādhi (1.42-3), and padmāsana facilitates holding the breath, which should induce kevalakumbhaka and samädhi (2.72-5). Also, śakticalana is the practice of moving kundalini, the raising of which is said elsewhere to induce samādhi (4.19-20).

114 These include Hathapradīpikā 3.60: 'When the uddiyāna lock is firm, liberation becomes spontaneous' (uddiyāne drịhe bandhe muktih svābhàviki bihavet). The 'spontaneous liberation' brought 
At the beginning of the fourth chapter, Svātmarāma notes that Rājayoga is known by many names, including samādhi, laya, tattva, amanaska, and jivvanmukti, among others (4.3-4). ${ }^{115}$ He was willing to understand the various nomenclature for samādhi as referring to the same meditative state, in the same way that earlier texts, such as the Amanaska, the Candrāvalokana, and the Yogatārāvalī, had done implicitly. In particular, his equating of jivvanmukti with Rājayoga and samādhi signals his intention to represent the type of liberation espoused in texts, such as the Amanaska and the Vivekamārtanda.

Svātmārāma's definitions of samādhi (4.5-7) are taken from the section of the Vivekamārtanda that was quoted above. ${ }^{116}$ After this, fourth chapter has eight verses that mention liberation. Five of these verses identify samädhi with liberation and can be traced to texts consulted for this study. Three verses are from the Amanaska's second chapter; ${ }^{117}$ one from the Gorakaśataka ${ }^{118}$ and one from the Candrāvalokana. ${ }^{119}$ Of the remaining three untraced verses, one identifies liberation with the death-like state of Rājayoga. The context is the attainment of samādhi through the practice of fusing the mind with an internal resonance (nādānusandhāna). When the mind and breath dissolve, the sound disappears and the yogin enters samädhi, the no-mind state:

Because of fusing the mind with an internal resonance, [the yogin's] accumulations of sin are destroyed. When the mind and breath surely dissolve in the stainless [state, the yogin] no longer hears the sound of the conch or kettle drum. His body certainly becomes like a piece of wood because of the no-mind state (unmanyāvasthā). The yogin, who is [now] free from all states [of mind] and free from all thoughts, remains like a corpse. [However,] he is undoubtedly liberated. The yogin immersed in samädhi is not consumed by time, bound by the result of action nor controlled by anyone. ${ }^{120}$

about by uddìnanabandha may follow from the fact that this technique conquers death (3.59). Also, Hathapradīpikā 3.103cd: 'This yoga [of practising vajroli] generates merit and gives liberation even when one indulges in pleasure' (ayam punyakaro yogo bhoge bhukte 'pi muktidah). Cf. Hathapradīpikā 3.94 (ayam śubhakaro yogo bhogayukto 'pi muktidah). I would like to thank Lubomír Ondračka for his insights into the relation between liberation and siddhāsana, padmāsana and uddiyānabandha.

115 For further discussion of the compilatory methods of Svātmārāma see Mallinson 2016b: 117-18.

116 Hațapradīpikā 4.5-6 = Vivekamārtanda 162-3, Hațapradīpikā 4.7 = Vivekamārtanda 164. Note that Svātmārāma omits the terms samprajñäta and asamprajñāta in his list of synonyms for Rājayoga. Also, Patañjali's definition of samādhi as cittavrttinirodha does not occur, which indicates that the Hathapradīpikā's teachings on Rājayoga were not influenced by the Pätañjalayogaśāstra.

117 Hathapradīpikā 4.8, 4.25, 4.112 = Amanaska 2.5, 27, 59.

118 Haṭapradīpikā 4.110 = Gorakșaśataka 7 .

119 Hațhapradīpikā 4.16 = Candrāvalokana 30.

120 Haṭhapradīpikā 4.105-4.108 (sadā nādānusandhānāt kșìyante pāpasamcayāh |nirañjane vilīyete niścitạ̣ cittamārutau || śànkhadundubhinādam ca na śrṇoti kadācana | kāṣthavaj jāyate deha unmanyāvasthayā dhruvam || sarvāvasthāvinirmuktah sarvacintāvivarjitah | mṛtavat tișthate yogī sa mukto nātra saṃśayah || khādyate na ca kālena bādhyate na ca karmaṇā| sādhyate na sa kenāpi yogī yuktah samādhinā). 
This passage is followed by other verses on samädhi that describe the yogin as free from sensory experience, waking, sleeping, and so on. These other verses are also taken from the Vivekamärtanda, ${ }^{121}$ the Gorakșáataka, ${ }^{122}$ and the Amanaska. ${ }^{123}$

Another important verse on liberation in the Hathapradipikä's fourth chapter suggests that Svātmārāma was aware that some traditions were not convinced that the attainment of samādhi was liberation. This verse (4.30) occurs in a passage on dissolution (laya) of the mind:

Whether [samädhi] is called liberation or not in other traditions, an exquisite bliss arises from the dissolution (laya) of the mind and breath. ${ }^{124}$

The above verse reveals Svātmārāma's attempt to distance the Hathapradīpikā from any controversy over whether the state of samädhi could be called liberation. Perhaps he had in mind the Yogabija's view that yoga without gnosis was insufficient for liberation. Instead of arguing the point, Svātmārāma reminds the reader of the value of Rajjayoga by pointing to the apparent consensus among these yogic traditions that samādhi generates bliss. ${ }^{125}$

The last of the eight verses on liberation (4.78) comments on the tantric view, namely that the liberated yogin becomes a second Siva. This view is introduced by Svātmārāma in a section on the four stages of yoga called àrambha, ghața, paricaya, and nispatti, which he borrowed from the Amaraughaprabodha. Samädhi occurs in the final stage called nispatti, which is explained as follows:

Then, [when nispatti is attained,] the mind becomes one and is called Rājayoga. The [yogin] becomes a creator and destroyer [of the world] and an equal to the god of yogins. ${ }^{126}$

Immediately after the above verse, Svātmārāma adds the following untraced verses, which qualify this view of liberation:

Whether this might be liberation or not, there is certainly uninterrupted [transcendental] happiness in it. This happiness, which arises in samādhi, is attained

121 Hațapradīpikā 4.109, 4.108, 4.113 = Vivekamārtanḍa 166, 168, 169.

${ }^{122}$ Hațhapradīpikā 4.110 = Gorakșaśataka $7 . \quad{ }^{123}$ Hathapradīpikā $4.112=$ Amanaska 2.59 .

${ }^{124}$ Hațhapradīpikā 4.30 (so 'yam evāstu mokșākhyo māstu vāpi matāntare| manahprānalaye kaś cid ànandah sampravartate).

125 Hațha- and Rājayoga texts appear to be consistent in describing samādhi as a blissful state, e.g. Amanaska 2.20-1, 2.100, Gorakṣaśataka 64, Vivekamārtanḍa 193, Yogabīja 151, Haṭapradīpikā 4.2, 4.30, etc.

${ }^{126}$ Haṭhapradīpikā 4.77 (ekībhūtam tadā cittam rājayogābhidhānakam | srṣțisaṃhārakartāsau yogiśvarasamo bhavet). 
because of Rājayoga. Those ignorant of Rājayoga merely perform Haṭhayoga. I think these practitioners are denied the fruit of their efforts. ${ }^{127}$

Although Svātmārāma was willing to accept the Saiva ideal of a yogin becoming an equal to Śiva, he qualified it by acknowledging that the attainment of Śivahood may not be accepted as liberation by all. It is possible that the notion of Sivahood was too sectarian to be the final goal of a system of yoga that was intended for a wide audience.

On the weight of the evidence, it appears that Svātmārāma favoured transcendence over power, by identifying the state of Rajjayoga with liberation. As demonstrated above, he borrowed a significant number of verses from the Vivekamārtanda, the Goraksaśataka, and the Amanaska, all of which support this viewpoint. More importantly, Svātmārāma placed most of these verses at the end of the Hathapradipikä's final chapter, which gives the impression that they represent his decisive view. Apart from a single hemistich of the Amaraughaprabodha, which is qualified by the verse that follows it, he omitted verses from earlier works that present the liberated yogin as an all-powerful god living in the world. Moreover, descriptions of a liberation characterized by siddhis are not prominent in the final chapter of the Hathapradipikā.

In grappling with the tensions between transcendence and power, Svātmārāma further simplified the notion of Rājayoga as liberation by eschewing the question of whether the liberated yogin continues to act in the world. In addition to leaving the Kaula view of the liberated yogin largely unrepresented, he omitted the relevant sections on action and rites in earlier yoga texts, such as the Amanaska and the Vasisthasamhitā. Although the Hathapradīpikā implies that the liberated yogin remains suspended in the hypometabolic state of samädhi, its open-ended conclusion was probably an invitation for gurus of various traditions to supply their own views on the yogin's fate after liberation.

\section{Concluding Remarks}

It is likely that Hatha- and Rājayoga arose independently as non-initiatory practices that were ancillary to various religions. By the twelfth or thirteenth century, Hathaand Rajjayoga were combined to form a distinct system that synthesized tantric teachings of various traditions, including Buddhism. Among the salient features of this system were physical yoga techniques and the goals of a blissful, stonelike samädhi and liberation-in-life. Not being the preserve of any one tradition, the codification of the Hatha-Rāja system produced trans-sectarian texts with minimal

\footnotetext{
${ }^{127}$ Haṭhapradīpikā 4.78-9 (astu vā māstu vā muktir atraivākhaṇititam sukham | layodbhavam idam saukhyạ̣ rājayogād avāpyate || rājayogam ajānantaḥ kevalaṃ hațikarminah | etān abhyāsino manye prayāsaphalavarjitān).
} 
philosophy or theology. It seems probable that this system became widespread in India because it had significant advantages over the praxis of more fully fledged ascetic and tantric traditions. For, on the one hand, unlike physical methods of tapasyā, such as sitting amid five fires, keeping the arms above the head and standing on one leg for twelve years, the Hatha-Rāja method did not harm the body, claimed to produce results relatively quickly, and had a range of practical benefits, such as healing diseases and inducing mental calm. The fact that Hathaand Rājayoga texts do not integrate or even mention the methods of tapasyā suggests that their authors were unwilling to conflate the two.

On the other hand, Hatha- and Rājayoga were simpler to understand and disseminate than Tantra's elaborate initiatory, doctrinal, and ritual systems, as well as the doctrines of Buddhism, Jainism, and Brahmanical philosophical schools (darśana), including Pātañjalayoga. The relative simplicity of the Hatha-Rāja method meant that it could be adapted for people of different religious beliefs. Its ancillary status ensured that it never became exclusive to one tradition. This produced a body of literature in which the same techniques are integrated with different systems of metaphysics and conceptions of liberation, which emphasize transcendence and power in varying degrees. This is seen clearly in the case of the Amaraughaprabodha, which adapted the three physical mudrās of the Amrtasiddhi, a Vajrayāna work, for a Śaiva audience by overlaying the same physical practice with Saiva metaphysics that included the raising of kundalinī, the attainment of Rājayoga, and the transformation of the yogin into a second Śiva (Birch 2019: 14-21). Through this process of adaptation, the Hatha-Rāja method crossed sectarian boundaries and evolved for a wide audience, including householders, and varying social conditions.

At some point, probably after the fifteenth-century Hathapradipikā, the older ascetic and tantric traditions responded to the success of Hatha- and Rajjayoga by reinterpreting and integrating the terminology and techniques of both yogas into their own doctrines. For example, ascetics reinterpreted the term hathayoga to mean the mental attitude required to succeed at tapasy $\bar{a} .{ }^{128}$ This meaning is absent in the yoga texts consulted for this chapter. Tantrikas incorporated techniques of Hatha- and Rājayoga into their compendiums as preliminary practices. ${ }^{129}$

\footnotetext{
128 On this definition of the term hațayoga among ascetics, see Bevilacqua 2016. I am not aware of any textual evidence that indicates that this meaning of Hathayoga predates the Hațapradīpikā.

129 For example, the Śaiva ritual compilations, the Puraścaranacandrikā (late fifteenth century) and the Puraścarañārnava (eighteenth century), incorporated Haṭhayogic āsanas and prānāyāmas as preliminary rites to mantra recitation. There are Hațhayogic āsanas in the Vaișnava compendium called the Surisarvasva (I wish to thank Rembert Lutjeharms for this reference). Also, some tantric compendiums that date to after the fifteenth century quote Hatha- and Rājayoga texts or tacitly borrow from them. Examples include the Prānatoṣin̄i $(1820 \mathrm{CE})$ of Rāmatoṣaṇa Vidyālañkāra, the Merutantra, Caturbhujamiśra's Mugdhāvabodhinī (on the Rasahṛdayatantra), the Praśnasaṃhitā, etc. The Värähītantra cannibalized much of the Hațapradīpikā.
} 
Brahmanical traditions responded by blending the teachings of Hatha- and Rājayoga with Pātañjalayoga in large compendiums and by transforming many Hatha- and Rājayoga texts into Upaniṣads. ${ }^{130}$ The integration of Hatha- and Rājayoga with the yogas of these more prominent traditions resulted in the demise of the Hatha-Rāja method as a distinct system of practice. By the eighteenth century, Hathayoga techniques characterized the auxiliaries of àsana and prānāyāma in aștāingayoga, and Rājayoga became little more than a label for the 'best yoga' of any tradition, regardless of whether samädhi was taught or not (Birch 2014: 412-16).

\section{Acknowledgements}

I would like to thank Prof. Gavin Flood for encouraging me to write this chapter and for reading several drafts, and (in alphabetical order) Jacqueline Hargreaves, Dr Ulrich Timme Kragh, Dr James Madaio, Dr James Mallinson, Dr Lubomír Ondračka, Shaman Hatley, and Dr Mark Singleton for their incisive comments on this work, as well as Prof. Diwakar Acharya and Prof. Dominic Goodall for their comments on passages from the Amaraughaprabodha and the Sivasamhitā. I would like to thank Dr S.V.B.K.V. Gupta for his assistance in reading the South Indian scripts of manuscripts of the Amaraughaprabodha, the Candrāvalokana, and the Yogatārāvalī. My work on this chapter received funding from the European Research Council (ERC) under the European Union's Horizon 2020 research and innovation programme (grant agreement No. 647963).

\section{References}

\section{Primary Sources (in English Alphabetical Order)}

Amanaska; see Birch, Jason. 2013.

Amaraughaprabodha

Amaraughaprabodha, (unpublished) critical edition, ed. Jason Birch. The Hatha Yoga Project, forthcoming.

\footnotetext{
${ }^{130}$ For example, the Yogacintāmaṇi of Godāvaramiśra (sixteenth century), the Yogacintāmani of Sivānandasarasvatī (seventeenth century), the Yuktabhavadeva (seventeenth century), the Hathasanketacandrikā (eighteenth century), the Upāsanasārasangraha (sixteenth century), the Yogasärasangraha (sixteenth to eighteenth century), etc. For the redacting of early Hatha- and Rājayoga texts into Upaniṣads, see Bouy 1994.
} 
Amṛtasiddhi

Amrtasiddhi, (unpublished) critical edition, ed. James Mallinson and Péter-Dániel Szántó. The Hatha Yoga Project, forthcoming.

Anubhavanivedanastotra

Abhinavagupta: An Historical and Philosophical Study. K.C. Pandey. Varanasi: Chaukhamba Amarabharati Prakashan, 1935.

Candrāvalokana

Candrāvalokana. Ms No. 75278. Adyar Library and Research Centre, Chennai.

Candrāvalokana. Ms No. 4344. Government Oriental Manuscript Library, Madras (Chennai).

Candrāvalokana. Ms No. 4345. Government Oriental Manuscript Library, Madras (Chennai).

Dattātreyayogaśāstra

Dattātreyayogaśāstra. (unpublished) critical edition, ed. James Mallinson (compiled with assistance from Alexis Sanderson, Jason Birch, Péter Szántó, and Andrea Acri). The Hatha Yoga Project, forthcoming.

Gheraṇdasaṃitā; see Mallinson, James. 2014.

Gorakșaśataka

Gorakșaśataka, (unpublished) critical edition, ed. James Mallinson. Hatha Yoga Project, forthcoming.

Gorakṣasiddhāntasangraha

Gorakṣasiddhāntasaingraha, ed. Pāṇḍeya, Janārdana Sāstrī. Varanasi: Varanaseya Sanskrit Vishvavidyalaya Press, 1973.

Haṭhapradīpikā

Hațapradīpikā of Svātmārāma, ed. Swami Digambaraji and Pt. Raghunatha Shastri Kokaje. Lonavla: Kaivalyadhama S.M.Y.M. Samiti, 1998.

Hathapradīpikā of Svātmārāma with the Commentary Jyotsnā Brahmānanda, ed. K. Kunjunni Raja. Madras: Adyar Library and Research Centre, 1972. ${ }^{131}$

Hațasañketacandrikā (of Sundaradeva)

Hațhasanketacandrikā. Ms No. 2244 at the Man Singh Pustak Prakash Library, Jodhpur.

Jyotsnā (of Brahmānanda)

Brahmānandakṛtā Hațhapradīpikā Jyotsnā, ed. Maheśānand, Śarmā, Sahāy, and Bodhe. Lonavla: Kaivalyadham Śrīmanmādhav Yogamandir Samiti, 2002.

Kuladīipikā

Kuladīpikā, Institut Français de Pondichéry Transcript, No. T1046a.

Kulārṇavatantra

131 Verse numbers are cited from this edition. 
Kulārnava Tantra, intro. Avalon, A., trans. Pandit, M.P., ed. Vidyāratna, T. Delhi: Motilal Banarsidass, 1984.

Kulasāra

Kulasāra. Ms No. NAK 4-137 (NGMPP A40/11). Kathmandu National Archives, Nepal. Kaulajñānanirṇaya

Kaulajñānanirnaya. Ms No. NAK 3-362 (NGMPP reel A48/13). Kathmandu National Archives, Nepal.

Kaulajñānanirnaya (chapters 5 and 17). Critical Edition, Shaman Hatley, Forthcoming.

Matsyendrasaṃhitā; see Kiss, Csaba. 2009. Matsyendranātha's Compendium (Matysendrasamhitā): A Critical Edition and Annotated Translation of Matysendrasaṃitā 1-13 and 55 with Analysis. Unpublished doctoral thesis, Oxford University.

Merutantra

Merutantra, ed. Pạ̣ḍita Raghunāthaśāstri. Śrivenkateśvara Bombay, 1908.

Mokṣopāya

Bhāskarakaṇth as Mokṣopāya-Tīkā: ein Kommentar in der Tradition der kaschmirischen Yogavāsișth a-.berlieferung, vol. 1-4, ed. Slaje, Walter. Graz: EWS-Fachverl., 1996.

Mokșopāya: Upaśāntiprakaraṇa. Kritische Edition von Susanne Krause-Stinner und Peter Stephan. (Anonymus Casmiriensis: Mokșopāya. Historisch-kritische Gesamtausgabe.) Herausgegeben unter der Leitung von Walter Slaje. Textedition. [Akademie der Wissenschaften und der Literatur, Mainz. Veröffentlichungen der Indologischen Kommission]. Wiesbaden: Harrassowitz [forthcoming].

Mrgendratantra

Mṛgendra, Vidyāpāda and Yogapāda, with the Commentary (-vrtti) of Bhatța Nārāyaṇakaṇtha, ed. Madhusudan Kaul Shāstrī. KSTS 50. Srinagar, 1930.

Mugdhāvabodhinī (of Caturbhujamiśra)

Govindbhagavatpada: Rasahrdayatantra with Caturbhuja Misra's Mugdhavabodhini.

Delhi: Chaukhambha Orientalia, 1989.

Pātañjalayogaśāstra

Pātañjalayogasūtrāṇi vācaspatimiśraviracitațīkāsamvalitavyāsabhāsyasametāni tathā bhojadevaviracitarājamārtandābhidhavrttisametāni, Ānandāśramasamskṛtagranth āvaliḥ, 47. ed. Kāśīnātha Śāstrī Āgāśe, Hari Nārāyaṇa Āpaṭe, Pune: Ānandāśramamudraṇālaya, 1904.

Pātañjala-Yogasūtra-Bhāsya Vivaranam of Śañkara-Bhagavatpāda, ed. Sastri, P.S. and Sastri, S.R.K. Madras: Government Oriental Manuscript Library, 1952.

Praśnasamhitā

Śrīpraśnasaṃitā, ed. Raghavan, V. Tirupati: Kendriya Sanskrit Vidyapeetha, 1969.

Puraścaraṇacandrikā (of Devendrāśrama)

Puraścaraṇacandrikā. Ms No. NGMPP A42/5, Kathmandu National Archives, Nepal. 
Puraścaraṇārṇava (of H.H. The Maharājā Pratāpa Śiṃha Sāha Bahādura of Nepaul)

Puraścaryārnavah, vols 1-3, ed. Śrīpaṇdita Muralidhara Jhā. Varanasi: Prabhakari \& Co. Banaras, 1901.

Prāṇatoṣiṇī (of Rāmatoṣaṇa Vidyālañkāra)

Prānatoșinī, ed. Bhattacaryya, J.V. Calcutta: Śrījīiānandavidyāsāgarabhatțācarya, 1898.

Rasārṇava

The Rasārnavam: or the Ocean of Mercury and other Metals and Minerals, ed. Ray, P.C. and Kaviratna, Hariścandra. Bibliotheca Indica, 174. Calcutta: Baptist Mission Press, 1910.

Sāṅkhyapravacanabhāṣya (of Vijñānabhiksu)

The Sämkhya-Pravacana-Bhāsya or commentary on the exposition of the Sānkhya philosophy, ed. Richard Garbe. Boston, Cambridge, MA: Harvard University Press, 1895.

Sārngadharapaddhati

Śārngadharapaddhati, ed. Peter Peterson. Delhi: Caukhambā Saṃkḳ̂ta Pratișthāna, 1987.

Śivasaṃitā

Śiva Saṃhitā: A Critical Edition, ed. Maheshananda Swami. Lonavla: Kaivalyadhama S.M.Y.M. Samiti, 2009; see Mallinson, James. 2007b.

Sūtasaṃhitā

Śrīmatsūtasaṃhitā tātparyadīpikāsahitā. Mylapore, Madras: Sri Balamanorama Press, 1932.

Surīsarvasva (of Govindakavibhūṣaṇasāmantarāya)

Sri Surisarvasvam, ed. Sri Jagannatha Misra. Calcutta: Asiatic Society of Bengal, 1912.

Upāsanāsārasañgraha

Upāsanāsārasañgraha, Institut Français de Pondichéry Transcript No. T1095b, pp. 15-63.

Vārāhītantra

Vārāhītantra, Ms No. 3-315 (B 144/9 (NGMCP 3-315)), Kathmandu National Archives, Nepal. ${ }^{132}$

Vasiṣthhasamhitā

Vasiștha Saṃhitā (Yoga Kānda), revised edition, ed. Philosophico-Literary Research Department. Lonavla: Kaivalyadhama S.M.Y.M. Samiti, 2005.

Vivekadarpana; see Reinelt, K.J. 2000. Das Vivekadarpana: Textanalyse und Erläuterungen zur Philosophie und praktischen Erlösungslehre der Nāthayogis in Mahārāștra. Inauguraldissertation zur Erlangung des Doktorgrades der Fakultät für Orientalistik und Altertumswissenschaft der Universität Heidelberg.

\footnotetext{
${ }^{132}$ I have used a transcript of this text available at muktabodha.org.
} 
Vivekamārtạ̣ḍa

Vivekamārtanda. Ms No. 4110. Maharaja Sayajirao Oriental Institute, Central Library, Baroda (Vadodara). ${ }^{133}$

Gorakșaśataka, ed. Fausta Nowotny. Cologne: K.A. Nowotny, 1976.

Yogabīja

Yogabija (unpublished) critical edition, ed. Jason Birch. The Hatha Yoga Project, forthcoming.

Yogabija of Gorakhanātha, ed. Ramalala Srivastava. Gorakhapur: Gorakhanath Mandir, 1982.

Yogacintāmaṇi (of Śivānandasarasvatī)

Yogacintāmaṇi, ed. Haridāsa Śarma. Calcutta: Calcutta Oriental Press (no date).

Yogacintāmaṇi (of Godāvaramiśra)

Yogacintāmaṇi. Ms No. 220, 1882-3. Bhandarka Oriental Research Institute, Pune.

Yogasārasangraha

Yogasārasañgraha. Institut Français de Pondichéry Transcript No. T0859.

Yogatārāvalī

Yogatārāvalī, (unpublished) critical edition, ed. Jason Birch. The Hatha Yoga Project, forthcoming.

Yoga Upanișads

Yoga Upanișads with the Commentary of Śri Upanișadbrahmayogin, ed. Pandit A. Mahadeva Sastri. Madras: Adyar Library and Research Centre, 1968.

Yogayājñavalkya

Yogayājñavalkya, ed. Sri Prahlad C Divanji. B.B.R.A. Society’s Monograph, no. 3. Bombay: Bombay Branch Royal Asiatic Society, 1954.

Yuktabhavadeva

Yuktabhavadeva of Bhavadeva Miśra, ed. M.L. Gharote and V.K. Jha. Lonavla: Lonavla Yoga Institute, 2002.

\section{Secondary Sources}

Bansat-Boudon, Lyne. 2013. 'The Contribution of Non-Dual Śaivism of Kashmir to the Debate on jivanmukti: A Thematic Perspective on the Question of Periodization'. Periodization and Historiography of Indian Philosophy, Eli Franco. Vienna: Verein 'Sammlung de Nobili, Arbeitsgemeinschaft für Indologie und Religionsforschung', Institut für Südasien-, Tibet- und Buddhismuskunde der Universität Wien.

${ }^{133}$ Verse numbers and readings are cited from this codex. 
Bevilacqua, Daniela. 2016. 'Let the Sādhus Talk: Ascetic Understanding of Hatha Yoga and Yogāsanas', Religions of South Asia, 11(2-3), 182-206. https://doi.org/10.1558/ rosa.37023.

Birch, Jason. 2011. 'The Meaning of Hatha in Early Hathayoga', Journal of the American Oriental Society, 131(4), 527-54.

Birch, Jason. 2013. The Amanaska: King of All Yogas: A Critical Edition and Annotated Translation with a Monographic Introduction. DPhil Dissertation. Oxford: University of Oxford Library.

Birch, Jason. 2014. 'Rājayoga: The Reincarnations of the King of All Yogas', International Journal of Hindu Studies, 17(3), 401-44.

Birch, Jason. 2015. 'The Yogatārāvalī and the Hidden History of Yoga', Nāmarūpa: Categories of Indian Thought, Issue 20, Spring. New York: Nāmarūpa Inc.

Birch, Jason. 2018a. 'Premodern Yoga Traditions and Ayurveda: Preliminary Remarks on Shared Terminology, Theory, and Praxis', History of Science in South Asia, 6, 1-83. doi: 10.18732/hssa.v6i0.25.

Birch, Jason. 2018b. 'The Proliferation of Āsanas in Late Medieval Yoga Texts', Yoga in Transformation: Historical and Contemporary Perspectives on a Global Phenomenon. Vandenhoeck \& Ruprecht Unipress, pp. 101-79.

Birch, Jason. 2019. 'The Amaraughaprabodha: New Evidence on the Manuscript Transmission of an Early Work on Hatha- and Rājayoga', Journal of Indian Philosophy, https://doi.org/10.1007/s10781-019-09401-5.

Bouy, Christian. 1994. Les Nātha-Yogin et les Upanișads. Paris: Di usion de Boccard.

Colas, Gerard. 2003. 'History of Vaișnava Traditions: An Esquisse', in Gavin Flood (ed.), The Blackwell Companion to Hinduism. Oxford: Blackwell.

Fort, Andrew. 1998. Jivvanmukti in Transformation: Embodied Liberation in Advaita and Neo-Vedanta. Albany, NY: State University of New York Press.

Golovkova, Anya. 2012. 'Śrīvidyāa, in K.A Jacobsen (ed.), Brill's Encyclopedia of Hinduism, Volume Four: Historical Perspectives, Poets, Teachers, and Saints, Relation to other Religions and Traditions, Hinduism and Contemporary Issues. Leiden and Boston, MA: Brill, Handbuch der Orientalistik, Zweite Abteilung, Indien, pp. 815-22.

Goodall, Dominic. 2015. The Niśvāsatattvasamhitā: The Earliest Surviving Saiva Tantra. Vol 1. A Critical Edition of the Mūlasūtra, Uttarasūtra and Nayasūtra, Goodall, Dominic, in collaboration with Alexis Sanderson and Harunaga Isaacson, with contributions of Kafle, Nirajan, Acharya, Diwakar, and others. Franco-German Early Tantra Series, École Française D’ extreme-orient Nepal Research Centre.

Harimoto, Kengo. 2014. God, Reason, and Yoga: A Critical Edition and Translation of the Commentary Ascribed to Śankkara on Pātañjalayogaśāstra 1.23-28. Hamburg: Department of Indian and Tibetan Studies, Universität Hamburg.

Hatley, Shaman. 2007. The Brahmayāmalatantra and Early Saiva Cult of Yoginīs. $\mathrm{PhD}$ thesis, University of Pennsylvania. 
Kaivalyadhama. 2005. Descriptive Catalogue of Yoga Manuscripts (Updated Edition). Lonavla: SMYM Samiti.

Kiss, Csaba. 2009. Matsyendranātha's Compendium (Matysendrasamphitā): A Critical Edition and Annotated Translation of Matysendrasamhitā 1-13 and 55 with Analysis. Unpublished doctoral thesis, Oxford University.

Leadbeater, C.W. 1925. The Masters and the Path. Chicago, IL: Theosophical Press.

Maas, Philipp André. 2006. Samādhipāda. Das erste Kapitel des Pātañjalayogaśāstra zum ersten Mal kritisch ediert. (Samädhipāda. The First Chapter of the Pātañjalayogaśāstra for the First Time Critically Edited). Aachen: Shaker (Studia Indologica Universitatis Halensis) (Geisteskultur Indiens. Texte und Studien 9).

Maas, Philipp André. 2014. 'Der Yogiund sein Heilsweg im Yoga des Patañjali', in Wege zumHeil(igen). Sakralität und Sakralisierung in hinduistischen Traditionen. Karin Steiner. Wiesbaden: Harrassowitz, pp. 65-90.

Mallik, Smt Kalyani. 1954. Siddhasiddhāntapaddhati and Other Works of Nath Yogis. Pune: Poona Oriental Book House.

Mallinson, James. 2004. The Gheranda Sam hitā: The Original Sanskrit and an English Translation. Woodstock, NY: YogaVidya.

Mallinson, James. 2007a. The Khecarīvidyā of Ādinātha: A Critical Edition and Annotated Translation of an Early Text of Hațayoga. London: Routledge.

Mallinson, James. 2007b. The Śiva Saṃhitā: A Critical Edition and an English Translation. Woodstock: YogaVidya.com.

Mallinson, James. 2011. 'The Original Gorakșaśataka' in David White (ed.), Yoga in Practice. Chicago, IL: Chicago University Press, pp. 257-72.

Mallinson, James. 2014. 'Hathayoga's Philosophy: A Fortuitous Union of NonDualities', Journal of Indian Philosophy, 42(1), 225-47.

Mallinson, James. 2016a. 'The Amṛtasiddhi: Hațhayoga’s Tantric Buddhist Source Text (Draft)'. Forthcoming in Saivism and the Tantric Traditions: Essays in Honour of Alexis G. J. S. Sanderson, edited by Dominic Goodall, Shaman Hatley, Harunaga Isaacson, and Srilata Raman. Gonda Indological Studies. Leiden: Brill, forthcoming. Available at: https://www.academia.edu/26700528/The_Amṛtasiddhi_Hathayogas_ Tantric_Buddhist_Source_Text (accessed 9.2.2017).

Mallinson, James. 2016b. 'Śāktism and Hațhayoga', in Bjarne Wernicke Olesen (ed.), Goddess Traditions in Tantric Hinduism, History, Practice and Doctrine. Oxford: Routledge, pp. 109-40.

Mallinson, James. 2019. 'Kālavañcana in the Konkan: How a Vajrayāna Hațhayoga Tradition Cheated Buddhism's Death in India', Religions, 10, 273; doi: 10.3390/ rel10040273.

Potter, Karl. 1998. Advaita Vedānta up to Śaṃkara and His Pupils. Delhi: Motilal Banarsidass.

Rama, Swami and Swami Ajaya. 1978. Living with the Himalayan Masters: Spiritual Experiences of Swami Rama. Honesdale: Himalayan International Institute of Yoga Sciences \& Philosophy. 
Reinelt, K.J. 2000. Das Vivekadarpana: Textanalyse und Erläuterungen zur Philosophie und praktischen Erlösungslehre der Nāthayogis in Mahārāșțra. Inauguraldissertation zur Erlangung des Doktorgrades der Fakultät für Orientalistik und Altertumswissenschaft der Universität Heidelberg.

Rukmani, T.S. 1997. 'Tension Between Vyutthāna and Nirodha in the Yoga-Sūtras', Journal of Indian Philosophy, 25, 613-28.

Sanderson, Alexis. 2014. 'The Śaiva Literature', Journal of Indological Studies (Kyoto), Nos. 24 and 25 (2012-13), pp. 1-113.

Saraogi, Olga Serbaeva. 2010. 'Liberation in Life and After Death in Early Śaiva Mantramārgic Texts: The Problem of Jìvanmukti', in Andreas Bigger, Rita Krajnc, Annemarie Mertens, Markus Schüpbach and Heinz Werner Wessler (eds.), Release from Life-Release in Life: Indian Perspectives on Individual Liberation. Bern, Berlin, Bruxelles, Frankfurt am Main, New York, Oxford, Wien: Peter Lang, pp. 211-33.

Schaeffer, Kurtis R. 2002. 'The Attainment of Immortality: From Nāthas in India to Buddhists in Tibet', Journal of Indian Philosophy, 30(6). Netherlands: Springer.

Slaje, Walter. 2000a. 'Towards a History of the Jivvanmukti Concept: The Mokșadharma the Mahābhārata', in Minoru Hara, Ryutaro Tsuchida, and Albrecht Wezler (eds.), Harānandalahari: Volume in Honour of Professor Minoru Hara on His Seventieth Birthday. Reinbeck: Dr Inge Wezler Verlag für Orientalistische Fachpublikationen, pp. 325-48.

Slaje, Walter. 2000b. 'Liberation from Intentionality and Involvement: On the Concept of jìvanmukti According to the Mokșopāya', Journal of Indian Philosophy, 28, 171-94.

Sternbach, Ludwik. 1974. Subhāșita, Gnomic and Didactic Literature. History of Indian Literature, vol. 4. Wiesbaden: Otto Harrassowitz.

Szántó, Péter-Dániel. 2016. A Brief Introduction to the Amrtasiddhi (Handout for a talk presented at the Hatha Yoga Project's Workshop, SOAS University of London). Available at: https://www.academia.edu/28522189/_A_Brief_Introduction_to_the_ Amrtasiddhi_Handout_for_Sanskrit_Texts_on_Yoga_London_Oxford_2016_ (accessed 9.2.2017).

Vasudeva, Somadeva. 2011. 'Powers and Identities: Yoga Powers and the Tantric Saiva Traditions', in Knut Jacobsen (ed.), Yoga Powers. Leiden: Brill, pp. 265-302.

Watson, Alex, Goodall, Dominic and Sarma, S.L.P. Anjaneya. 2013. An enquiry into the Nature of Liberation: Bhatta Ramakantha's Paramoksanirasakarikavrtti, a commentary on Sadyojyotih's refutation of twenty conceptions of the liberated state (mokșa), for the first time critically edited, translated into English and annotated. Pondichery: École française d'Extrême-Orient.

Wezler, Albrecht. 2001. 'Letting a Text Speak: Some Remarks on the Sādhanapāda of the Yogasūtra and the Yogabhāṣya. I. The Wording of Yoga- sūtra 2.22', Journal of Indian Philosophy, 29, 293-304.

Yogananda, Paramahamsa. 1946. Autobiography of a Yogi. Los Angeles, CA: SelfRealization Fellowship (1954, (1) 1946). 